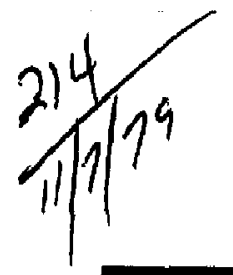

\title{
Af. 263
}

\section{HAZARDS CONTROL PROGRESS REPORT NO. 57 , October through March 1979}

R. V. Griffith: Scientific Editor

August 20, 1979

\section{MASTER}

Work performed under the auspices of the U.S. Department of

Energy by the UCLLL under contract number W-7405-ENG -48.
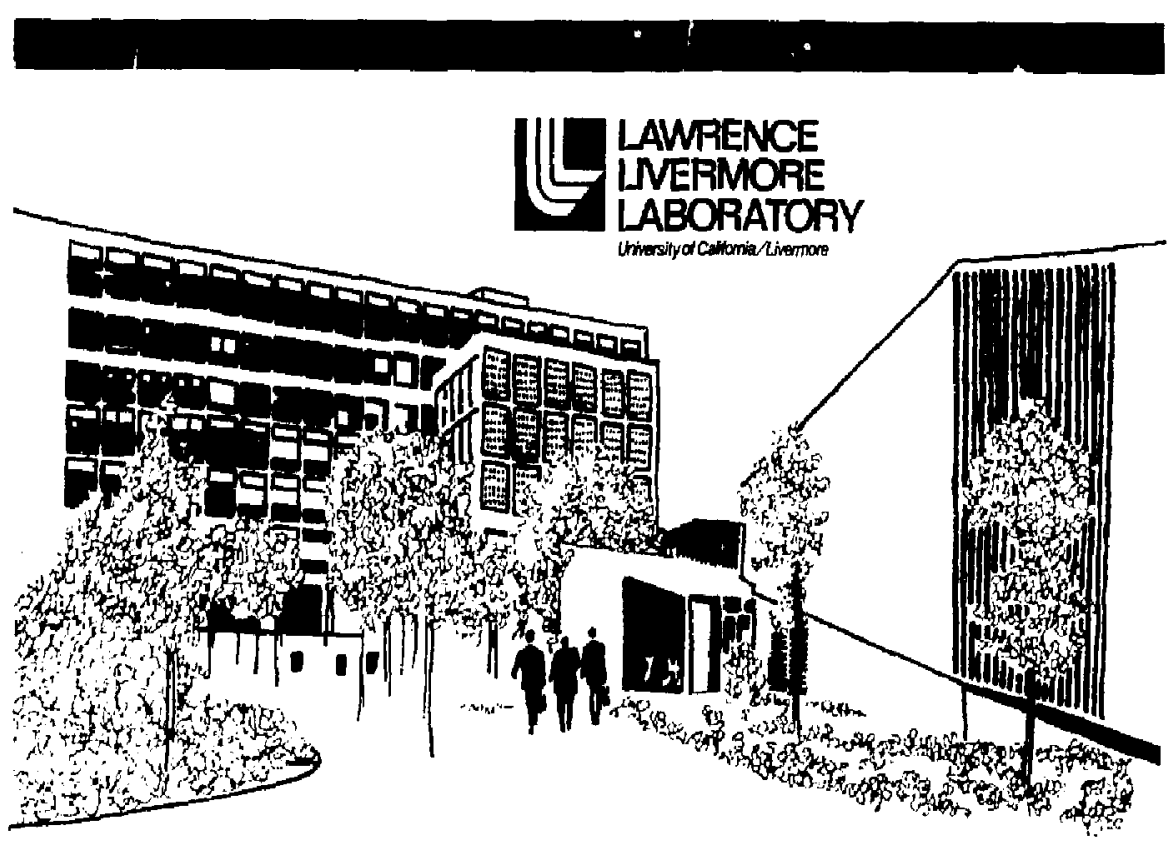


\section{迧 \\ LAWRENCE LNERMORE LABORATORY \\ University of Cafforia/Livermore, Callomia/94550}

UCRL-50007-79-1

\section{HAZARDS CONTROL PROGRESS REPORT NO. 57 October through March 1979}

R. V. Sriffith: Scientific Editor

Manuscript date: August 20, 1979

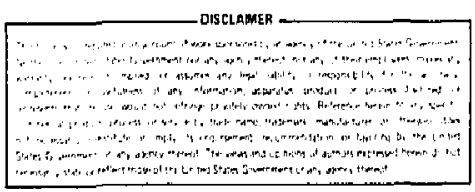




\section{FOREWORD}

This report is divided into three major sections. The first section. Progress Reports, covers the status of activities undertaken or continuing during the period; additional reports or separate publications will cover the final results of these activities. The second section, Technical Notes, contains reports on interesting activities of a more linited scope on which further reporting is not anticipated. The third section lists recent publications.

Readers who are inleresled in more detail regarding aily item may contuct the authors of the reports listed in the Contents. 


\section{CONTENTS}

PROGRESS REPORTS $\ldots \ldots \ldots \ldots \ldots \ldots \ldots \ldots \ldots \ldots \ldots \ldots$

Fire Safely

Gas Chromatographic/Mass Spectrometric Analysis of

Thermal Degradation Products from Wcod and Composite

Burns (A. E. Lipska and $M$. F. Jeffries)

Corrosion in the Experimental Ducting of

the Fire Test Cell $(D, G$, Beason) $\ldots \ldots \ldots \ldots \ldots \ldots \ldots \ldots \ldots \ldots$

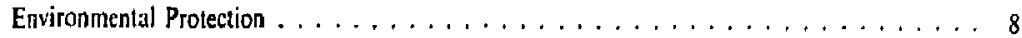

On-Line X-Ray Fluotescence Analysis of Transition

Metals in Waste Water: Phase II $(J$. L. Cote, Sr.,

D. W. Rueppel, and M. A. Matthews) $\ldots \ldots \ldots \ldots \ldots \ldots \ldots \ldots$

Indust rial Hygiene $\ldots \ldots \ldots \ldots \ldots \ldots \ldots \ldots \ldots \ldots \ldots \ldots \ldots$

Fire Environmental Tests for Self-Contained

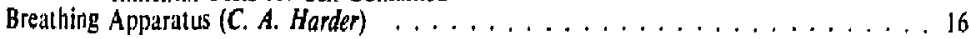

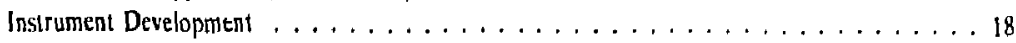

Developments in Neutron Spectrometry (J. H. Thorngate and

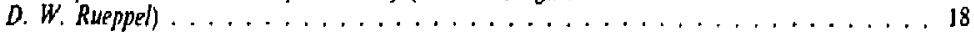

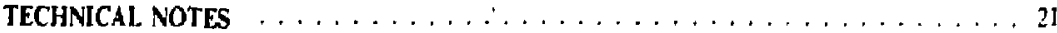

Radiation Protection $\ldots \ldots \ldots \ldots \ldots \ldots \ldots \ldots \ldots \ldots \ldots \ldots \ldots \ldots$

Intermediate Energy X-Ray Spectra for General

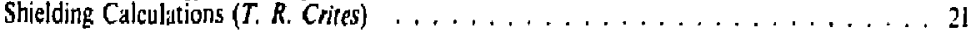

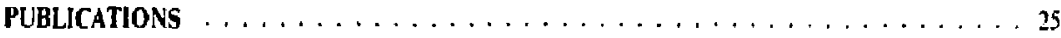

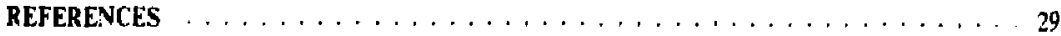




\section{HAZARDS CONTROL PROGRESS REPORT NO. 57 October through March 1979}

\section{PROGRESS REPORTS}

\section{FIRE SAFETY}

Gas Chromatographic/Mass Spectrometric Amalysis of Thermal Degradation Products from Wood and Composite Burns

Introduction. In fiscal year 1979 we chemically antalyed the combustion products from wood and composite burns to determine the cause of HEPA filter plugging. ' Our preliminary results suggested that filter plugging might be caused by the concenIration of thermal degradation products rathet than by the production of specific chemicals. This year, using a more advanced method, we reanalyzed the combustion products to verify the 1979 findings.

Experimental Method, Wood cribs and cribs construced of polyvinylchloride, wood, polymethylmethacrylate, polycarbonate, and fiber-reinforced plistic (composite cribs) were burned in a large fiet test cell, and the combustion products were directed into the ductwork, which houses a rolling prefilter and a HEPA filter (Fig. I). For a better understanding of the combustion products and their effect on the filters, we sumpled products upstream and downstream of the HEPA filter and upstream of the rolling preffler. The various sampling points are shown in Fig. I.

Wi used a vacuum pump to pull the combustion products into glass traps set in a Dewar flask filled with liquid nilrogen. The products were sampled al 5 -min intervals, beginning $5 \mathrm{~min}$ atter the onset of the burn. Each sampling period lasted 5 min. This approach allowed us to include any possible changes in either the quantity or kinds of combustion products generated during the burn. After the samples were trapped, they were brought lo room temperature, exiricted with chloroform, and stored in a refrigtrator until gas chromatoıraphic/mass spectrometric (GC/MS) analysis.

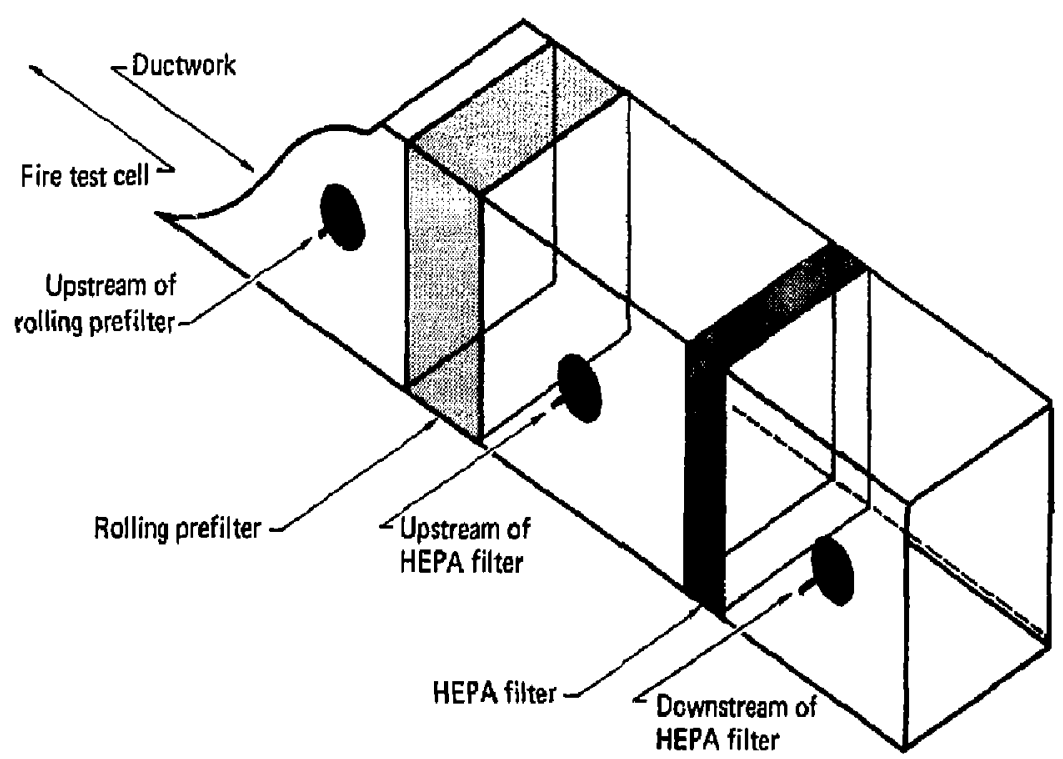

FIG. I. Dustwork housing the rolling prefilter and the HEPA filler. Sampling points are shown. 
For a better understanding of the types of products couting the HEPA filter and the prefiller, we exlracted a concentraled 2 -g sample of each filler with $60 \mathrm{ml}$ of chloroform in a Soxhlet extractur. In this process hot solvent is vaporized, condensed, and dropped on the sulid substance contuined in the thimble. The extructed compounds contained in the liquid fill the body of the extractor and aulomaljcilly siphon into the flask. The process continues repeatedly at the solvent is vaporized and condensed.

The degradation products were analyzed on (wo) capilliary glass columns, the SP 2100 and the SE-30. Buth columns were $30 \mathrm{~m}$ long and had approximately 60,000 theoretical plates. Column temperature was programned from $9010225^{\circ} \mathrm{C}$ at a rale of $5^{\circ} \mathrm{C} / \mathrm{min}$, and injection port temperalure was sul at $300^{\circ} \mathrm{C}$. The flame ionization detector ween, its transfer line, and the transfor line between the gus chromalogriph (GC) and the ion source of the mass spectrometer (MS) were maintained at $250^{\circ} \mathrm{C}$. Nitrogen, our make up gas, wass sat at a flow rate of $60 \mathrm{ml} / \mathrm{min}$ al the detector's inlet. A platinum-iridium line split the effluenl between our quadrupole MS and the flame ionization deteclor. allowing simultaneous recording of the chromalngruphic pesks and total ion counts as a function of time. Wo used the computerized Wiley library containing the mass spectra* ${ }^{*}$ to find the dominant neaks in the chromatograms and then compared the spectra of suspected compounds with the spectril of each chroniatographic peak to further idenify the compontents.

Results. The results of the GC/MS antalysis are summitrized in Tables 1-5, Each lable shows the burn parameters' the compaunds collected on, near. and extracted from the HEPA filter or the prefilter: the retention time for each compound (i.t., the time required for it to elute off the column from the time of injection): and the concentration of each compuund. We have expressed the concenirations in terms of peak heights: keep in mind, however, that these are not absolute concentrations betallse we did not use internal stindards in our analywis.

"Compiled by Hewleti-P:achird.

Table 1. Degradation products from wood bum 41.

\begin{tabular}{|c|c|c|c|c|c|}
\hline $\begin{array}{c}\text { Butn } \\
\text { panmeters }\end{array}$ & $\begin{array}{l}\text { Retention } \\
\text { time. } \min ^{3}\end{array}$ & $\begin{array}{l}\text { Products } \\
\text { upstresm of } \\
\text { HEPA filter }\end{array}$ & ILEPA fijter extracls & $\begin{array}{l}\text { Products } \\
\text { downstreim of } \\
\text { llLPa filter }\end{array}$ & $\begin{array}{c}\text { Semi- } \\
\text { quantitstive } \\
\text { comparisonb }\end{array}$ \\
\hline \multirow{2}{*}{$\begin{array}{l}\text { Moisture contenc } \\
\text { of wood (Douglas } \\
\text { fir) was } 8-11 \%\end{array}$} & 1.70 & & Phunal & & 3 \\
\hline & 1.90 & $\begin{array}{l}\text { o-phenol, binzal- } \\
\text { deliyde acetophanone }\end{array}$ & & & I \\
\hline $\begin{array}{l}\text { Prefiller was not } \\
\text { modified. }\end{array}$ & 2.20 & $\begin{array}{l}\text { 2,2-ar-metliylstyrenc, } \\
0 \cdot \text { metliylstyrere, } \\
\text { a-methylstyrene }\end{array}$ & & & 2 \\
\hline \multirow{6}{*}{$\begin{array}{l}\text { Timp max } \\
\text { in eed], } 740^{\circ} \mathrm{C} \\
\text { in cell at cxhnust. } \\
70^{\circ} \mathrm{C} \\
\text { in ducs at HEPA } \\
\text { Jry, } 60^{\circ} \mathrm{C} \\
\text { wel, } 60^{\circ} \mathrm{C}\end{array}$} & 2.38 & & & $o, m, p$-cresols & 3 \\
\hline & 2.57 & & $0, m, p$-cresols & & 3 \\
\hline & 2.70 & $\begin{array}{l}0, m, p \cdot c r e s o l s, \text { indane } \\
\text { melhyplienyhectylene }\end{array}$ & & & 3 \\
\hline & 3.30 & 2-methylbenzofuren & & & 2 \\
\hline & 3.47 & & 3,4-dimethylphenol & 3,4-dimuthylphenol & $2,1^{\mathrm{C}}$ \\
\hline & 3.72 & & mothylphenol & methylphenul & 2.] \\
\hline \multirow{2}{*}{$\begin{array}{l}\text { Vuntilation } \\
\text { inilial. } 2501 / 5 \\
\text { final. } 1251 / 5\end{array}$} & 4.05 & 1-methyl-1H-indene & & & 3 \\
\hline & 4.25 & & raphtholene or azulene & $\begin{array}{l}\text { nophthalt'nt or } \\
\text { naphthalene }\end{array}$ & 3.5 \\
\hline \multirow[t]{7}{*}{$\begin{array}{l}\text { Time to plugging, } \\
810 \mathrm{~s}\end{array}$} & 4.50 & $\begin{array}{l}\text { maphthakene or } \\
\text { azulenc }\end{array}$ & & & 5 \\
\hline & 5.62 & & intane-l-ano & & 1 \\
\hline & 6.20 & & I-metloylnaphthalent & 1-'7athylnaphtlılen' & 2 \\
\hline & 6.32 & & $\begin{array}{l}\text { 2-methylnaphthalent } \\
\text { of } 5,6 \text {-bensobicyclo } \\
(2,2,1) \text {-hept-2-tene }\end{array}$ & $\begin{array}{l}\text { 2-motliylnaphihalene } \\
\text { ot } 5,6 \text {-bentobicyclo } \\
(2,2,1) \text {-hept-2-ens }\end{array}$ & $\begin{array}{l}2 \\
2\end{array}$ \\
\hline & 6.70 & $\begin{array}{l}\text { 2-mothylnaphihalene } \\
\text { or } 5,6 \text {-bentobicycto } \\
(2,2,1) \text {-hept-2-cne }\end{array}$ & & & 3 \\
\hline & 6.90 & & tans+cinnamic acid & & 1 \\
\hline & 7,47 & & biphenyl & biphenyl & 2 \\
\hline
\end{tabular}


Table 1. Continued.

\begin{tabular}{|c|c|c|c|c|c|}
\hline $\begin{array}{c}\text { Burn } \\
\text { paymeters }\end{array}$ & $\begin{array}{l}\text { Retention } \\
\text { time, min? }\end{array}$ & $\begin{array}{l}\text { Phoducts } \\
\text { upstream of } \\
\text { HEPA filter }\end{array}$ & HEPA filler extracts & $\begin{array}{l}\text { Products } \\
\text { downstiom of } \\
\text { IEPA filter }\end{array}$ & $\begin{array}{c}\text { Srmi- } \\
\text { quastítative } \\
\text { comparisonb }\end{array}$ \\
\hline & 7.87 & & benzo (c) einnolinc & & 1 \\
\hline & 7.90 & biphenyi & & & 2 \\
\hline & 8.30 & $\begin{array}{l}\text { 1,2-dimethyinaph- } \\
\text { thalene }\end{array}$ & & & 1 \\
\hline & 8.80 & & setsaphthalene & acenaphutatene & 4 \\
\hline & 9.00 & unidentilied & & & 2 \\
\hline & 9.40 & $\begin{array}{l}\text { acenaphuhakenc or } \\
\text { bjphenylene }\end{array}$ & & & 3 \\
\hline & 9.60 & & & $\begin{array}{l}\text { 6-metly|l.6-phenyl } \\
\text { fulvere }\end{array}$ & 1 \\
\hline & 10.10 & unidentilied & & & 1 \\
\hline & 10.23 & & dibenzofuran & dibenzoluran & 2 \\
\hline & 10.70 & unidentifics & & & 1 \\
\hline & 11,90 & & f.nethyl nuorene & & 2 \\
\hline & 12.11 & unidentificd & & & 1 \\
\hline & 12.30 & & $\begin{array}{l}\text { Muorene or Jipheny] } \\
\text { diazomet lasne }\end{array}$ & & 2 \\
\hline & 12.50 & unidentifited & & & 1 \\
\hline & 15.411 & & $\begin{array}{l}\text { phenanthresse or } \\
\text { anthracene }\end{array}$ & $\begin{array}{l}\text { plrenanthrtne or } \\
\text { anthratenc }\end{array}$ & 5,3 \\
\hline & 16.17 & phesanthrene & & & 2 \\
\hline & 16.90 & & 1-melhyl.3.phenylindare & I-melhyl-3-phenylindant & 1 \\
\hline & 17.70 & & $\begin{array}{l}\text { 9,10-phenanlhraquinone } \\
9,10 \text {-anthraquinone }\end{array}$ & $\begin{array}{l}\text { 9,10-phunanthraquinone } \\
\text { or 9,10-anthraquinone }\end{array}$ & 2 \\
\hline & 19.00 & & $\begin{array}{l}\text { dibenzoheptafulvene or } \\
\text { 2-phenylazphthalene }\end{array}$ & $\begin{array}{l}\text { dibenzohoplafulvene ur } \\
\text { 2-phenylsaphilhalene }\end{array}$ & 1 \\
\hline & 20.70 & & pyrene or fluoranthene & pyrente or fluosnthene & 3.1 \\
\hline & 21.00 & & $\begin{array}{l}1,2, j[0 \mathrm{I}-\text { tetrallydro } \\
\text { fluoranthene }\end{array}$ & & 2 \\
\hline & 21.57 & & pyrene & pyrene & 3,1 \\
\hline
\end{tabular}

\footnotetext{
${ }^{3}$ The amount of time required for 1 compound to clute of the column from the time of injection.

${ }^{b}$ Coneentraturns are expressed in ternis of peak heights: 5 indicales a very prominent peak (a very thigh concentration): 4 . a prominert peak (a high concentration): 3, a madium size peak (a medium concentration): 2, a small peak (a low concentration): and $I, 2$ very small peak (a wery low concentration).

GTwu numbers signily that (1) the same compounds have emerged from the GC column at the sume time of (2) that a peak is comprised of two different compounds.
}

We found that the pyrolysis and combustion products from the wood burns and the composite burns were similar, probably because wood was id major component of the compositc cribs. Both types of burns generated a lumber of aromatic and polynucleat components (e.g., cresol, phenanthrene, naphthalene), some of which are the dominant compounds formed during the first $5 \mathrm{~min}$ of the burns. Most of the dominant compounds have high molecular weights and high boiling points (abowe $200^{\circ} \mathrm{C}$ ) and are heavict than water, solid in their pyre form, and soluble in organic solvents (Table 6).
We detected substantial amounts of polycyclic compounds upstreats of the HEPA filler, downstrum of the prefiltur, on the HEPA filter. and on the prefilker but found only insubstantial alnounts downstream of the HEPA filter.

In comparing the smoke constituents from wood and composite burns, we find that composite burns generate more uerosol isomers and more phenols than wood burns and that wood burns form more polynuclear components but fewer simple aromalics than composite burns. In addition, composite burns generate $\mathrm{HCl}, \mathrm{HBr}$, and probably a number of halogenated organics. The halogenated 
Table 2. Degradation products fram waod bum 42.

\begin{tabular}{|c|c|c|c|c|}
\hline $\begin{array}{c}\text { Burn } \\
\text { paramecters }\end{array}$ & $\begin{array}{l}\text { Retention } \\
\text { time, } \min ^{2}\end{array}$ & $\begin{array}{l}\text { Products upstrosm } \\
\text { of HEPA filicr }\end{array}$ & $\begin{array}{l}\text { Products } \\
\text { downstream of } \\
\text { HEPA filter }\end{array}$ & $\begin{array}{l}\text { Semiquantitative } \\
\text { comparisont }{ }^{b}\end{array}$ \\
\hline \multirow{7}{*}{$\begin{array}{l}\text { Wuisture cunent } \\
\text { of wood (Douglas } \\
\text { fir) was 7-11\%. } \\
\text { Pre(titer consisted } \\
\text { of a single jayer of } \\
\text { s0\% efficieney } \\
\text { media breked by } \\
\text { a plastie grid. }\end{array}$} & 1,90 & Otphenol & No significont peaks & 2 \\
\hline & 280 & o.p-cresols & & 2 \\
\hline & 4.00 & $m_{1} /$ / cthylphenols & & 1 \\
\hline & 4.60 & azulene or naphthalene & & 2 \\
\hline & 6.00 & ind an-1·one & & 1 \\
\hline & 6.40 & styrene & & 1 \\
\hline & 6.80 & 2-methylnaphithalene & & 1 \\
\hline \multirow{6}{*}{$\begin{array}{l}\text { Temp mis } \\
\text { in cell. } 750^{\circ} \mathrm{C} \\
\text { in cell at exhiause, } \\
250^{\circ} \mathrm{C} \\
\text { in Juct } 31 \text { HEPA } \\
\mathrm{dry}, 80^{\circ} \mathrm{C} \\
\mathrm{Wel}, 68^{\circ} \mathrm{C}\end{array}$} & 9.40 & acenaphithalent & & 3 \\
\hline & 10.40 & 2-naphthnl & & 3 \\
\hline & 10,80 & dikenzofuran & & 3 \\
\hline & 11.80 & phenalenc & & 2 \\
\hline & 12.23 & Fuorens & & 2 \\
\hline & 12.67 & 4-methylfluorent & & 2 \\
\hline \multirow{3}{*}{$\begin{array}{l}\text { Ventibtion } \\
\text { initial, } 260 \mathrm{~J} / \mathrm{s} \\
\text { final, } 198 \mathrm{l} / \mathrm{s}\end{array}$} & 1350 & unidentified & & 2 \\
\hline & 14.60 & m-phenylpilienotole & & 2 \\
\hline & 15.20 & unidentificed & & 2 \\
\hline \multirow[t]{15}{*}{ Time to plugging, $510 \mathrm{~s}$} & 16.30 & phenanthrene or anthracene & & 5 \\
\hline & 17.70 & dihenzoheptafulvene & & 2 \\
\hline & 18.50 & 9-7ucrenune & & 3 \\
\hline & 19.00 & 4,5-methylene-phenasilisene & & 3 \\
\hline & 19.60 & dibutylphthatete & & 2 \\
\hline & 19,90 & unidentifittd & & 2 \\
\hline & 20.60 & unidentified & & 1 \\
\hline & 21,60 & Nowonthene & & 4 \\
\hline & 22.10 & 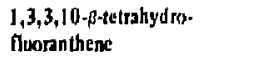 & & 2 \\
\hline & 22.70 & pyrene & & 4 \\
\hline & 25.15 & 2,3 benzofluorene & & 1 \\
\hline & 25.17 & 4.methylpyicte & & 1 \\
\hline & 26.90 & 2,3-benzolluarene & & I \\
\hline & 31.33 & 2,13-benzofluoranthene & & 2 \\
\hline & 34.30 & 3,4-henzophenanthrenc & & 2 \\
\hline
\end{tabular}

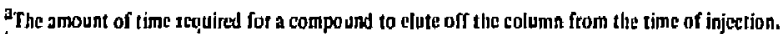

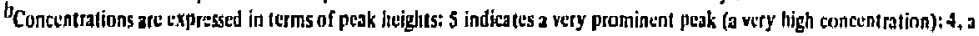
prominent ptak (a high concentration); 3. a medium size peak (a medium concentration):2, a small pesak (a tow concentration): and 1. a very simall peak ( a very low concemiation).
}

organics, hawever, were not detected on the columns we used.

If we were to analyze the physical properties of the main consituents of both types of burns, we would probably lind that the dominant compounds dissolve in some of the organic solvents und become airborne through the duclwork in the form of a fine mist that condenses on the walls of the duclwork and the HEPA filter. Furthermore, because the temperature near the HEPA filter is between 50 and $60^{\circ} \mathrm{C}$, we could probably expect compounds with higher boiling points to deposit on the lilleter.

Conclusion and Kecommendation. The overall results of this study suggest that filter plugeging is not caused by the unique chemical makeup of one compound or group of compounds but ruther by a coneentration effect.

Beciuse our analytical method wals aimed at detecting only the predominest differences among the degradition products of each burn. we did not look at truce components or examine how the various compounds dutected were fornied. The GC 
Table 3. Degradation products from composite burn 43.

\begin{tabular}{|c|c|c|c|c|}
\hline $\begin{array}{c}\text { Burn } \\
\text { parametets }\end{array}$ & $\begin{array}{l}\text { Retention } \\
\text { time, } \min ^{b}\end{array}$ & $\begin{array}{l}\text { Products upstrem } \\
\text { of HEPA filter }\end{array}$ & $\begin{array}{l}\text { Products } \\
\text { dow nstream of } \\
\text { HEPA filter }\end{array}$ & $\begin{array}{l}\text { Semiquantistive } \\
\text { comparison }\end{array}$ \\
\hline \multirow{7}{*}{$\begin{array}{l}\text { Composite crib made } \\
\text { of wood (Doughas fir) } \\
\text { uith a moisturc con- } \\
\text { tent of } 7-87 \text {, poly- } \\
\text { vinylchloride, poly- } \\
\text { melhylmethactybte, } \\
\text { polycarbonate, and } \\
\text { fiberreinfored } \\
\text { plastic." }\end{array}$} & 1.22 & a-xylene & No significan! perks & 5 \\
\hline & 1.30 & cycloontatelacte & & 4 \\
\hline & 1.67 & pherrol & & 3 \\
\hline & 1.83 & isopropylbenzene & & 2 \\
\hline & 1.93 & $\begin{array}{l}\text { cyclopropylbenzene ur } \\
\text { allylbenzcnc }\end{array}$ & & 2 \\
\hline & 2.30 & mahylphenylacetylene & & 3 \\
\hline & 3.28 & 1,2-disydronaphthalene & & 1 \\
\hline \multirow{3}{*}{$\begin{array}{l}\text { Prefilter consisted } \\
\text { of two byers of } 50 \% \\
\text { cfficiency medis and } \\
\text { one byys of } 10 \% \\
\text { cfliciency media. }\end{array}$} & 360 & naphtiakene & & 4 \\
\hline & 5.67 & bjphenyl & & 2 \\
\hline & 10.22 & pheranthrene & & 2 \\
\hline \multicolumn{5}{|l|}{$\begin{array}{l}\text { Temp max } \\
\text { in cell, } 640^{\circ} \mathrm{C} \\
\text { in cell at exhaust, } \\
160^{\circ} \mathrm{C} \\
\text { in duct at HEPA } \\
\text { ory, } 59^{\circ} \mathrm{C} \\
\text { wei, } 48^{\circ} \mathrm{C}\end{array}$} \\
\hline \multicolumn{5}{|l|}{$\begin{array}{l}\text { Ventilation } \\
\text { initial, } 2501 / \mathrm{s} \\
\text { final, } 2201 / \mathrm{s}\end{array}$} \\
\hline \multicolumn{5}{|l|}{$\begin{array}{l}\text { Pressure drop } \\
\text { actoss filter } \\
\text { initial, } 200 \mathrm{~Pa} \\
\text { fins, } 540 \mathrm{~Pa}\end{array}$} \\
\hline Timt to plugging, $410 \mathrm{~s}$ & & & & \\
\hline
\end{tabular}

\footnotetext{
atol firc rclarded.
}

${ }^{\forall}$ The amount of time required for a compound to clute off the column from the time of injection.

Concentrations are expessed in temts ori pesk heights: 5 , indieat's a very frominent peak (a very high concentration); 4 . a prominent peak (a high concentration); 3, a medium sizc peak (a medium concentration); 2, a small peak (a low concentration); and 1, a very small peak (a very low concentration).

tolumns used in this analysis were not specific for halogenated compounds, and therefore, is number of the compounds that may have formed in the composite burns may have gone undetecled. These could have been irreversibly absorbed on the columns or perhaps formed in such low quantities that they were masked by other products. In the latter tase, they would not have been deteeled by the MS heciuse of backgrnund inturference.

A moft detailed analysis of the degradation products and their mechanism of formation would require that wc:

1. Use capillaty columns specific for halogenated compounds and polynuclear compounds.
2. Pyrolyze wood and plistic samples stpurattely and introduce their degradiation products diteclly onto a GC columin before they have a chunce to react and form secondary und tertiary reaction products,

3. Develop a simpling system that traps pyrolysis and combustion products as well as trace components.

4. Devise a sumple work-up technique to use before we inject the samples onto the analytical column.

However, we believe that we have found the major cause of HEPA filter plugging and that further research in this area would be of secondary importance to filtration chemistry. 
Table 4. Degradation products from composite burn 45 .

\begin{tabular}{|c|c|c|c|c|}
\hline $\begin{array}{c}\text { Burn } \\
\text { paramaters }\end{array}$ & $\begin{array}{l}\text { Rctention } \\
\text { time, min } b\end{array}$ & $\begin{array}{l}\text { Products upsticam } \\
\text { of JEPA rilter }\end{array}$ & $\begin{array}{l}\text { Froducts behind } \\
\text { prcfilter (sampled } \\
\text { is the first } 5 \mathrm{~min} \text { ) }\end{array}$ & $\begin{array}{l}\text { Semiquantibative } \\
\text { comparison } \mathrm{c}\end{array}$ \\
\hline \multirow{4}{*}{ 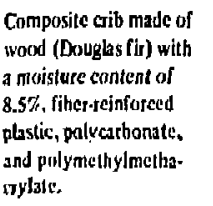 } & 1.20 & $\begin{array}{l}o, p \cdot x y l e n e s \\
\text { ethyibunzence }\end{array}$ & & 5 \\
\hline & 1.27 & cyclooctatetmene & & 3 \\
\hline & 1.57 & phenyl-N.methylcarbonate & & 3 \\
\hline & 1.92 & $\begin{array}{l}\text { I -etchoxytricyclo }(4,3,2,0) \\
\text { I0-azo-2,4,10-undecatricne }\end{array}$ & $\dot{.}$ & 2 \\
\hline \multirow{8}{*}{ 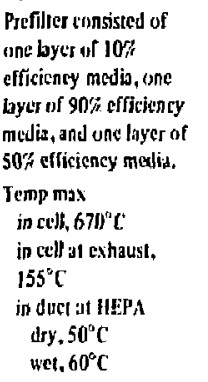 } & 2.37 & $\begin{array}{l}\text { U-citsol } \\
\text { metliylphenylacetylene }\end{array}$ & & 4 \\
\hline & 3,45 & p-utllyiphtnol & & 3 \\
\hline & 4.07 & naphthalenc & & 4 \\
\hline & 4.35 & $\begin{array}{l}\text { m-isopropylphenol or } \\
n \text {-isopropyiplicnol or } \\
p \text {-isopropylphand }\end{array}$ & & 2 \\
\hline & 5.80 & 1.metlyynaphtialene & & 2 \\
\hline & 6.07 & $\begin{array}{l}5,6 \text { benzobicyclo }(2,2,1) \\
\text { lept-2-line }\end{array}$ & & 2 \\
\hline & 7.20 & biphenyl & & 2 \\
\hline & 8.58 & biphenylene & & 2 \\
\hline \multirow{2}{*}{$\begin{array}{l}\text { Ventilation } \\
\text { initial, } 2501 / \mathrm{s} \\
\text { findl, } 2301 / \mathrm{s}\end{array}$} & 11.27 & $\begin{array}{l}\text { nydroxy-3.6. dimethyl } \\
\text { benzzldehydu }\end{array}$ & & 2 \\
\hline & 11.70 & 1,1-bicycloliephalriose & & J \\
\hline \multirow{9}{*}{$\begin{array}{l}\text { Pressure urop } \\
\text { actoss filict } \\
\text { initist. } 200 \mathrm{~Pa}_{3} \\
\text { rimsl. } 500 \mathrm{~Pa} \\
\text { Time to plugging, } 880 \mathrm{~s}\end{array}$} & 12.07 & diphenyldizzonethane & & 1 \\
\hline & 12.65 & diphenylpropane & & 1 \\
\hline & 12.97 & p-alpha-amylphenol & & 1 \\
\hline & 13.67 & 1.1-diphtnyletlene & & 1 \\
\hline & 14.20 & anthraquinone & & 1 \\
\hline & 15.20 & phenantlirenc & & 2 \\
\hline & 19.12 & & di-N-ptopylnaphthalate & 1 \\
\hline & 23.73 & & di-2-alhy/hexy/naphthalate & 5 \\
\hline & 26.98 & & butyl-butoxyethylnaphahala ic & 3 \\
\hline
\end{tabular}

\section{Corrosion in the Experimental Ducting of the Fire Test Cell}

In Jutruary of 1979 we completed replacement of the experimental ducting connected to the fire test cell (Fig. 2) operated by the Fire Science Group of Hazards Control, Special Projects Division. The ducting is constructeu of 16-gauge carbon steel sheeting, material similar to that used in most commercial applicutions. The tcmperature of the gases enlering the ducting varies; it can be as high as $250^{\circ} \mathrm{C}$, though it averages about $140^{\circ} \mathrm{C}$.

Since January 1976, when the lirst experimentul fire was ignited, the ducting has been exposed to smoke and combustion products of approximateiy 75 fires. Typical fuels tested were Douglas fir wood, polyvinylchloride (PVC) sheet, fiherglass-reinforced polyester resin, polycarbonatt shcel, and acrylic sheet (PMMA-FR). Fucl arrangements iere from simple crib to complex full-scule laboratory muck up configuration.

Chemicul analysis of the smoke showed a large concentration of hydrochloric acid and an indication of hydrobromic acid. Hydrochlusic acid can be generated by the combustion of PVC, hydrobromic acid by the combustion of PMMA-FR. Boin caused corrosion in the ducting. Coating the inside of the 
Table 5. Degradation products from composite burn 46.

\begin{tabular}{|c|c|c|c|c|c|c|}
\hline \multirow{2}{*}{$\begin{array}{c}\text { Burn } \\
\text { parameturs }\end{array}$} & \multirow{2}{*}{$\begin{array}{l}\text { Retention } \\
\text { time. min } b\end{array}$} & \multirow{2}{*}{$\begin{array}{c}\text { Spxhlet extract } \\
\text { of prefilter }\end{array}$} & \multicolumn{3}{|c|}{ Products sampled bellind profilter } & \multirow{2}{*}{$\begin{array}{c}\text { Semi- } \\
\text { quantitative } \\
\text { comparisonc }\end{array}$} \\
\hline & & & $5 \min$ & $10 \mathrm{~min}$ & 15 min & \\
\hline \multirow{7}{*}{$\begin{array}{l}\text { Compusite crib } \\
\text { made of wood } \\
\text { (Douglas fir) } \\
\text { with a moisture } \\
\text { content of } 8.5 \% \text { ' } \\
\text { fiber-reinfored } \\
\text { Instic, yoly- } \\
\text { cathonate. anb } \\
\text { polymellyyl- } \\
\text { methacrylate. }\end{array}$} & 1.37 & & & & etlylbenrent & 3 \\
\hline & 1.40 & & & 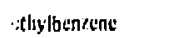 & & \\
\hline & 1.48 & & & & $\begin{array}{l}\text { styrenc, } \\
\text { cyclowstale- } \\
\text { traene }\end{array}$ & 5 \\
\hline & 1.50 & & & $\begin{array}{l}\text { styrun:, } \\
\text { cyctooctutetrount }\end{array}$ & & 3 \\
\hline & 1.60 & phenot & & & & 3 \\
\hline & 1.97 & & & prienol & & 了 \\
\hline & 2.00 & & & & $\begin{array}{l}\text { plienyl- } \\
\text { methyltarbonate }\end{array}$ & 4 \\
\hline \multirow{3}{*}{ 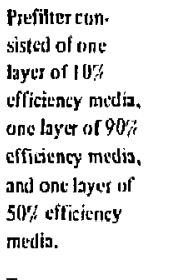 } & 2.22 & & & & $\begin{array}{l}\text { isopropyl } \\
\text { benzente }\end{array}$ & 2 \\
\hline & 2.25 & & & 4-muthylstyremt & & 2 \\
\hline & 2.37 & & $\begin{array}{l}\text { 1-(2-etlony. } \\
\text { propoxyl) } \\
\text { propannl-2 }\end{array}$ & $\begin{array}{l}\text { 4-methylstyrene, } \\
\text { ar-mstlylsyfens. } \\
\text { allylbenzene cy: } \\
\text { ulo| ropylhenzene }\end{array}$ & 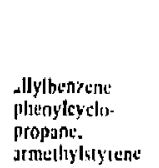 & $1.2^{\mathrm{d}}$ \\
\hline \multirow{6}{*}{ 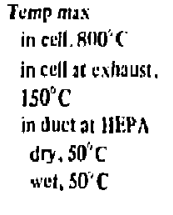 } & 2.90 & & & & o, $/ 1 \cdot$ cresols & 4 \\
\hline & 2.95 & & & $0 . j \cdot$ crectsols & & 5 \\
\hline & 3.70 & $p-4$ thylpheinol & & & & 3 \\
\hline & 4.311 & mophthinlente & & & & 3 \\
\hline & 4.32 & & & m,p-c|lhylphencls & & 2 \\
\hline & 4.45 & & & $\begin{array}{l}\text { 1.2-dihydronaph- } \\
\text { thalene }\end{array}$ & & 2 \\
\hline \multirow{2}{*}{$\begin{array}{l}\text { Ventilatiun } \\
\text { initial. } 250 \mathrm{~V} / \mathrm{s} \\
\text { final. } 30 \mathrm{~J} / \mathrm{s}\end{array}$} & +.57 & & $\begin{array}{l}\text { naplithalıne } \\
\text { or arultene }\end{array}$ & & & 2 \\
\hline & 4.68 & m-tsopropy|r.|ltenol & & & & 2 \\
\hline \multirow{11}{*}{$\begin{array}{l}\text { Pressure drop } \\
\text { scross titter } \\
\text { inilial, 251) Pa } \\
\text { finat, } 2950 \mathrm{Ps} \\
\text { Time io flugging. } \\
1320 \mathrm{~s}\end{array}$} & 4.93 & & & $\begin{array}{l}\text { nuphthalent. } \\
\text { azulıne }\end{array}$ & naphlabalene & 4.4 \\
\hline & 5.32 & & & 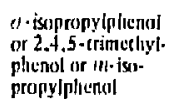 & & 1 \\
\hline & 6.20 & $\begin{array}{l}\text { 1-methylnaph- } \\
\text { linolene }\end{array}$ & & & $\begin{array}{l}\text { 3. isoprnpy. } \\
\text { phienyl-N. } \\
\text { methyliustonate }\end{array}$ & 1.1 \\
\hline & 6.52 & 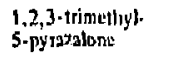 & & & & 3.1 \\
\hline & 6.92 & & & 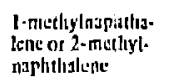 & & 2 \\
\hline & 7.72 & $\begin{array}{l}\text { biphenyl or } \\
\text { acenaphellalcre }\end{array}$ & & & & 2 \\
\hline & 8.50 & & & $\begin{array}{l}\text { Jutnaplotlalens } \\
\text { or biphtenyl }\end{array}$ & & 2 \\
\hline & 9.13 & acenaphthalene & acenaplitislone & & & 2.2 \\
\hline & 9.87 & $\begin{array}{l}\text { dipheriylmethane, } \\
\text { allyitsaphithalens, } \\
\text { acenaphitislene }\end{array}$ & & & & 1 \\
\hline & 10.00 & & & $\begin{array}{l}\text { acinaphittialene } \\
\text { of biphenylens. }\end{array}$ & & 2 \\
\hline & 10,57 & dibenzoiuran & & & & 1 \\
\hline
\end{tabular}


Toble 5. Comtinued.

\begin{tabular}{|c|c|c|c|c|c|c|}
\hline \multirow{2}{*}{ Mutn } & \multirow{2}{*}{$\begin{array}{l}\text { Kuttontion } \\
\text { lime, minh }\end{array}$} & \multirow{2}{*}{$\begin{array}{l}\text { Soxpluet extraci } \\
\text { of profilder }\end{array}$} & \multicolumn{3}{|c|}{ Prowlucts sompled belund prefilier } & \multirow{2}{*}{ 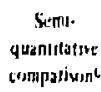 } \\
\hline & & & $5 \min$ & II) min & $15 \min$ & \\
\hline & 12,42 & 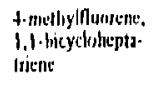 & & & & 1 \\
\hline & I2.KII & 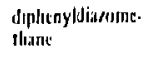 & & & & 1 \\
\hline & & & & Dunatenc & nuoren: & 2.1 \\
\hline & 15.37 & & & f-methylflumertie & & \\
\hline & 15.59 & & phesiznlinene & & & 2 \\
\hline & 15.92 & pherasilltetere & & & & 3 \\
\hline & 16,48 & dniluracen! & & & Dilentustlititeme & 1.1 \\
\hline & $16, y\}$ & & & pilenasntituenc & & 2 \\
\hline & 17.32 & 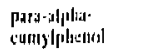 & & & & 2 \\
\hline & $1 k, 34$ & 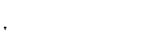 & & inilustilied & & 1 \\
\hline & 19.27 & & & $\begin{array}{l}\text { 1-muthylphtental } \\
\text { lireste: }\end{array}$ & & I \\
\hline & 19.58 & $\begin{array}{l}\text { WilsenfoluptofuJ. } \\
\text { vent }\end{array}$ & & & & $\mathrm{J}$ \\
\hline & 19.67 & & & $\begin{array}{l}\text { 4-metliy|pluenan- } \\
\text { threne }\end{array}$ & & 1 \\
\hline & 211.65 & & & $\begin{array}{l}\text { 2. plenylngylle. } \\
\text { thatene }\end{array}$ & & 1 \\
\hline & 21.25 & $\begin{array}{l}\text { Jiuersanthene } \\
\text { or pyrent }\end{array}$ & & & & 2 \\
\hline & 22.24 & & & Alemenatlentix & & 1 \\
\hline & 22.91 & pyrtil: & & $\begin{array}{l}\text { 1.2,3, t.itirahy. } \\
\text { droflumbathene }\end{array}$ & & 5.1 \\
\hline & $23,+5$ & & & & & \\
\hline & 31.41 & 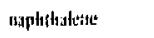 & & pyrene & & 1 \\
\hline
\end{tabular}

Sioll fire rutatdid.

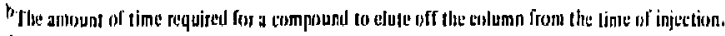

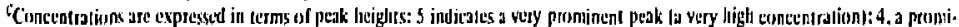

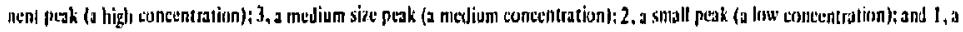
very small pusk (a very low concentration).

"Two numbers signify that (1) the same contpounds have umurged feom the column at the same time or (2) that a patk is comprised of Iwo different cumpoands.

ducting with at special corrusion-ectistitnt paint or resin-which wi did not do when llo duct was injtially instulled-would have prevented this

The major arcias of corression are stown in Fig, 3a-g. The most severe corrosion took place at the weld locitions (Fig. 3b), probubly because of the stress arcus set up during the welding of the shet' melial to the angled iron frame. Large Rakes of rust found in the hottom of the ducling corroborate this. Other points of severe corrosion are indicuted in Fig. 3d, f, and g. Very little corrosion was noted on the slanted scelion connecting the high-and lowexhaust points (Fig. 3c).

When we installed the new ducling, we noliced thit in the early morning there was a large amount of moisture on the upper inside surfaces, This moisture would accelerate corrosion and account for corrosion on the upper inside surlittes. In an alltempt to reduce this problem, we coisted the inside surfaces with an epoxy painl recomnended by our puint shop. This coating should provide a high resisitunte to corrosion caused by hydrochloric atid.

\section{ENVIRONMENTAL PROTECTION}

\section{On-Line X-Ray Fluorescence Analysis of Transition Metals in Waste Water: Phase II}

Introduction. Previously we reported the incouraging results of a feasibility study on the use of $x$-ray fluorescence analysis (XRFA) in an on-line monitor for metals in waste water. ${ }^{2}$ We have subsequently built a prototype monitoring system utilizing a dedicaled model LSI-II microprocessor 
Tahli 6. Plyysicit constants of the main organic compounds.

\begin{tabular}{|c|c|c|c|c|c|}
\hline Compound & $\begin{array}{l}\text { Plyyaical } \\
\text { Jpp:aranse }\end{array}$ & bp. C & mip. $\quad$ ( & Drnsily & Stolubility \\
\hline 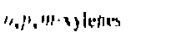 & Iyquid, wilid & $1] 4-1+4$ & $.+5-13$ & $11.56 \mathrm{st}$ & slculur, cther, ofganie solvenis \\
\hline phendnilusere & $\begin{array}{l}\text { Blue Ilunescitat } \\
\text { (tn vilutann) }\end{array}$ & $3+10$ & I101 & $1.1 \times 2 u$ & 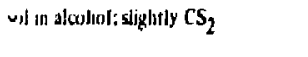 \\
\hline uthilbenzene & liquild & $\mathbf{I} \mathbf{k}$ & -19.4 & 11.9672 & alcoturl, cthers \\
\hline a. Af crevils & 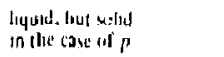 & $|!|-20 \mid$ & $11-5+4.8$ & $1.11+60$ & alculiol, cthee, orgonic solvents \\
\hline 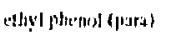 & whld therester & 219 & $+5-4 t$ & & alcohtul. ether, bentent, CSy \\
\hline nzphilialener & 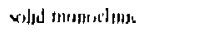 & 2(1) & 811,22 & 1.1450 & cther, alicolont. bentene. CS? \\
\hline Muaratlision: & paley yellow artalles & 375 & 111 & 1.25211 & 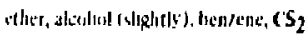 \\
\hline myent' & pale ytullon & $2(1,1)$ & $|q|-|5|)$ & 1.2710 & sol in alculks) \\
\hline 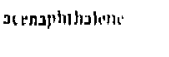 & 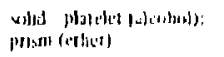 & $265-275$ & 92 & 19.8986 & 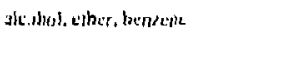 \\
\hline 2-niplithess & 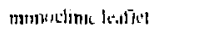 & 295 & 122 & 1.2800 & alcolwf, etler bintente, slughts $\mathrm{SO}_{2}$ \\
\hline $\begin{array}{l}\text { ditrentriluran } \\
\text { anthructere }\end{array}$ & 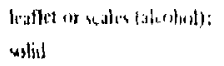 & 247 & $\begin{array}{l}86.87 \\
2 ! 6\end{array}$ & $\begin{array}{l}1.08464 \\
1.25130\end{array}$ & 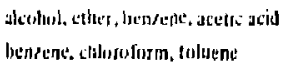 \\
\hline
\end{tabular}
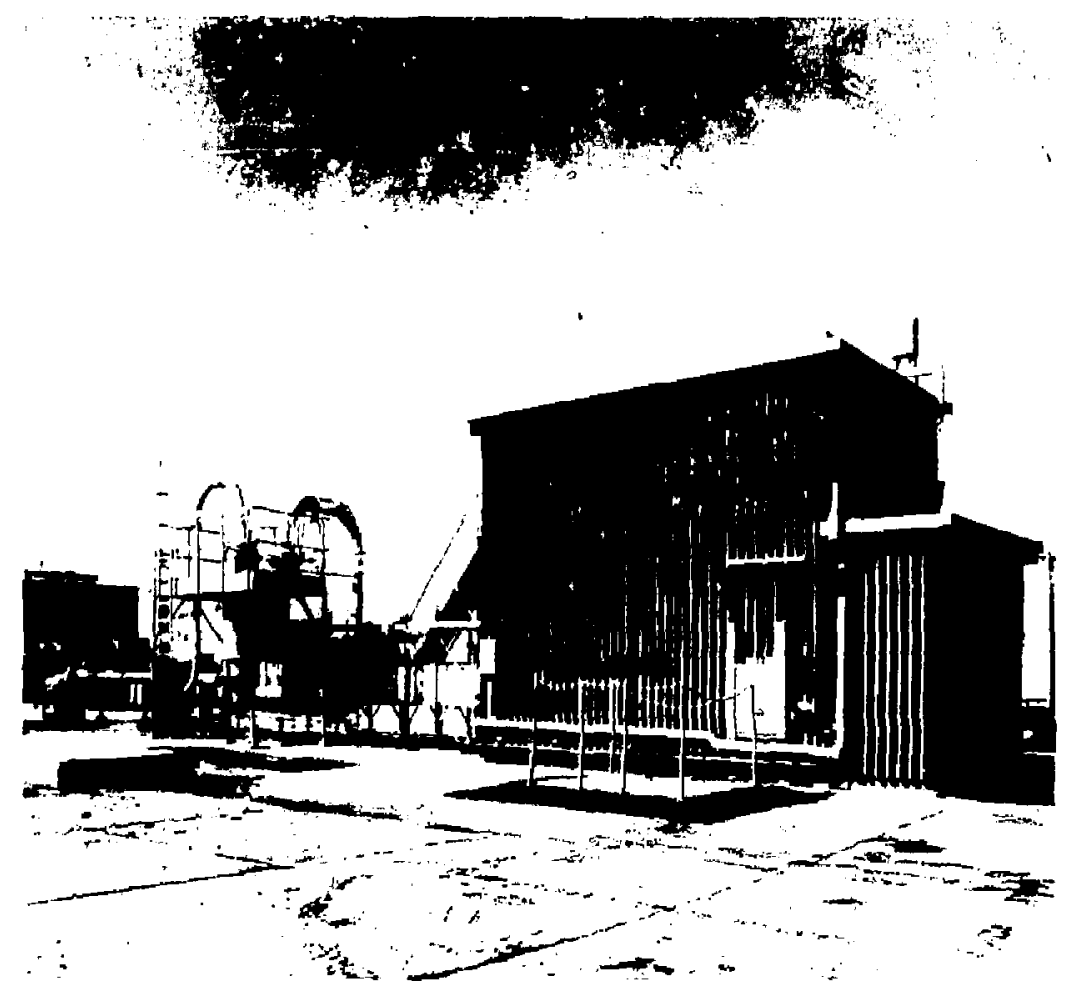

FIG. 2. Experimental ducting of the fire test cel!. 


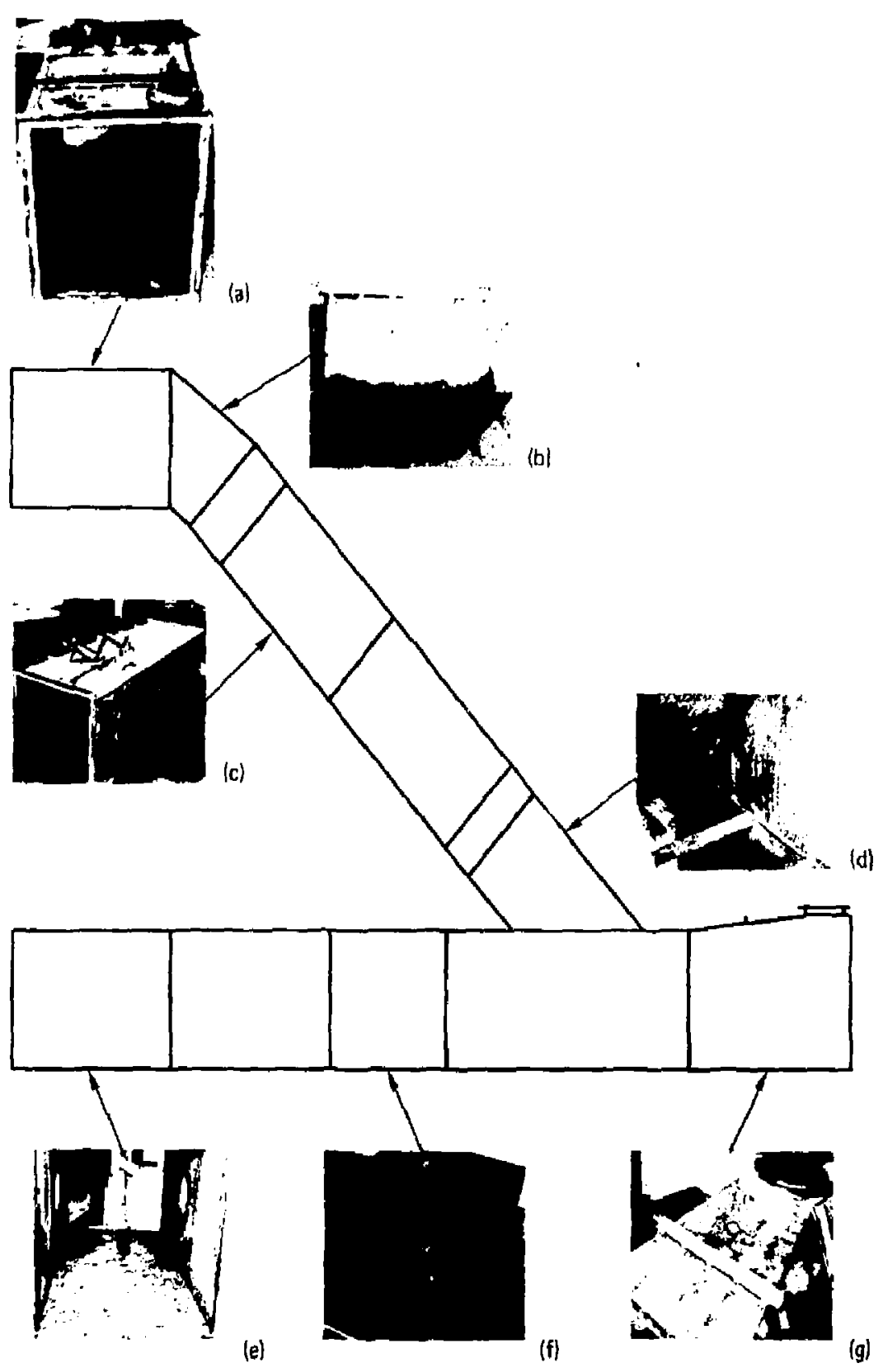

FIG. 3. Major areas of corrosion in the experimental ducting of the fire test cell. 


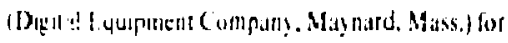
data collection and andisis. We have tested and wlibrilled the problotype in the lathoratury, installed st an-linc, and are now in the presesw of "debuge!limp" It.

Equipmont. Our etrlice notk shewed that the test resule sere othesined when as simple of the wastic waler steam flowed under lbe detector assembly m the lof of of at thin (i rimplaster, batked hy a pulyethystenc film and atir. Thexe metisures are necessirs to optunise sjgnal-9o-batckground satios. "Batkeround" in the instanct is lhe sipmal from purt water, wheh is caused primirily by scatlered photom from the enciling source. The geonetry

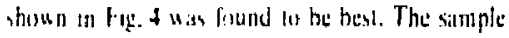
lume, complete wilh detector-source holder, is shown in 1 igs 5 . h. and 7 . The seciting source is

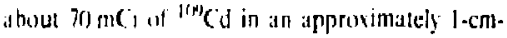
dlam divk conleguratuon. The detcetor is an incepenwe de $\mathrm{CO}_{2}$ filled proportional tounter. Signals from in are reuted va an OHTEC IOPPC pream- plofier to a Tennelec TC-202BLR amplifier and an analoge-fo+digital adjustor (ADC), designed and buil by R. Kiefer of our Electrical Enginecring Group. The original ADC had setupt differsmial linearity problems so we eventually replaced it with one of higher resolution and "threw atsa" the lesst signifiem disla hils. The digitab data are sored as a 256-chatnnel pulse-hejght spectrum in the LSI-II mutroprosessor.

Date Reduction. 'Tushe spettral regions of inlerest are defilled by software: one telleted on the predoninant $x$-ray line fer eath of eleven clements." and one centered on the lirete peak from the Compton-scattored photons from the source. Counts dre atounulated for sonte moderate period (currently ed at $5(0) \mathrm{s}$ ) and the integrils for wath region ate found. Each x-say region inlegral is divided by lie scalter inlegrill. Using this ratio climinates errors calused hy suree dectiy, moderale

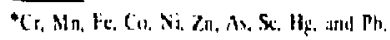

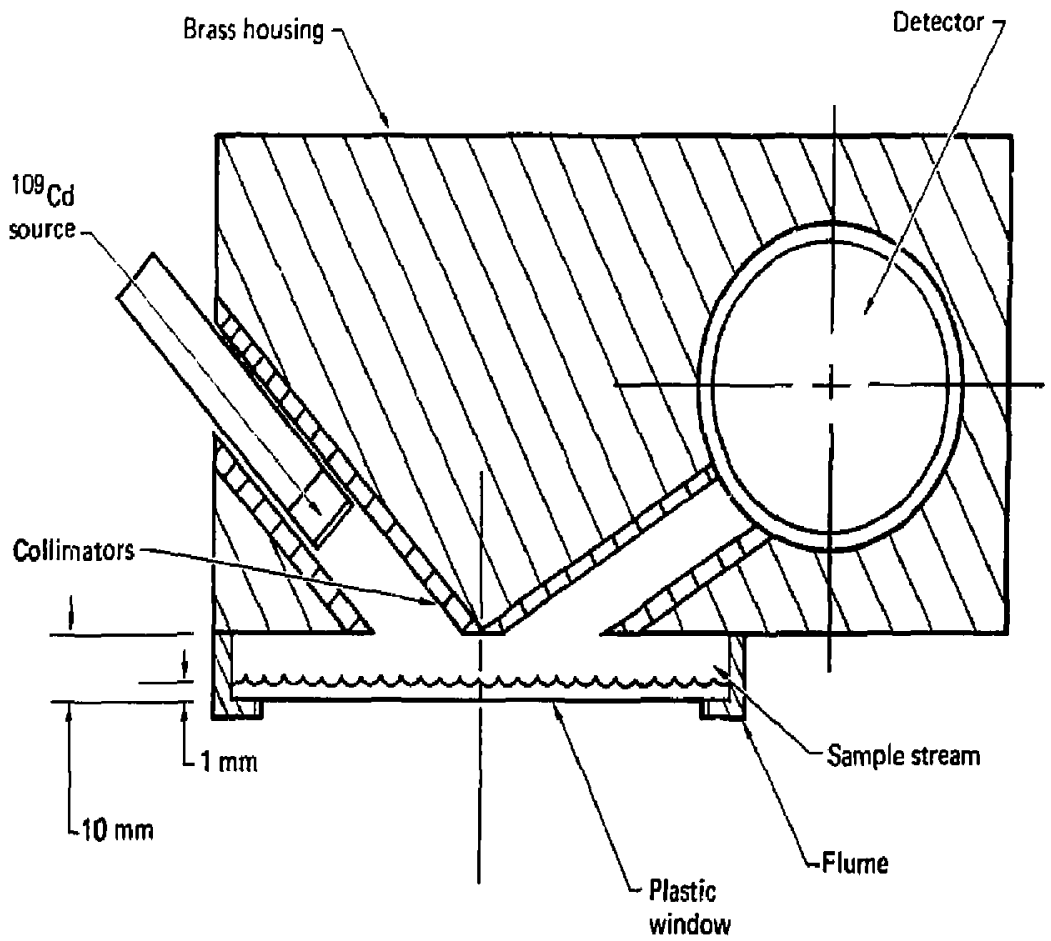

FIG. 4. Cross section of source-detector geometry for the XFRA monitor. 


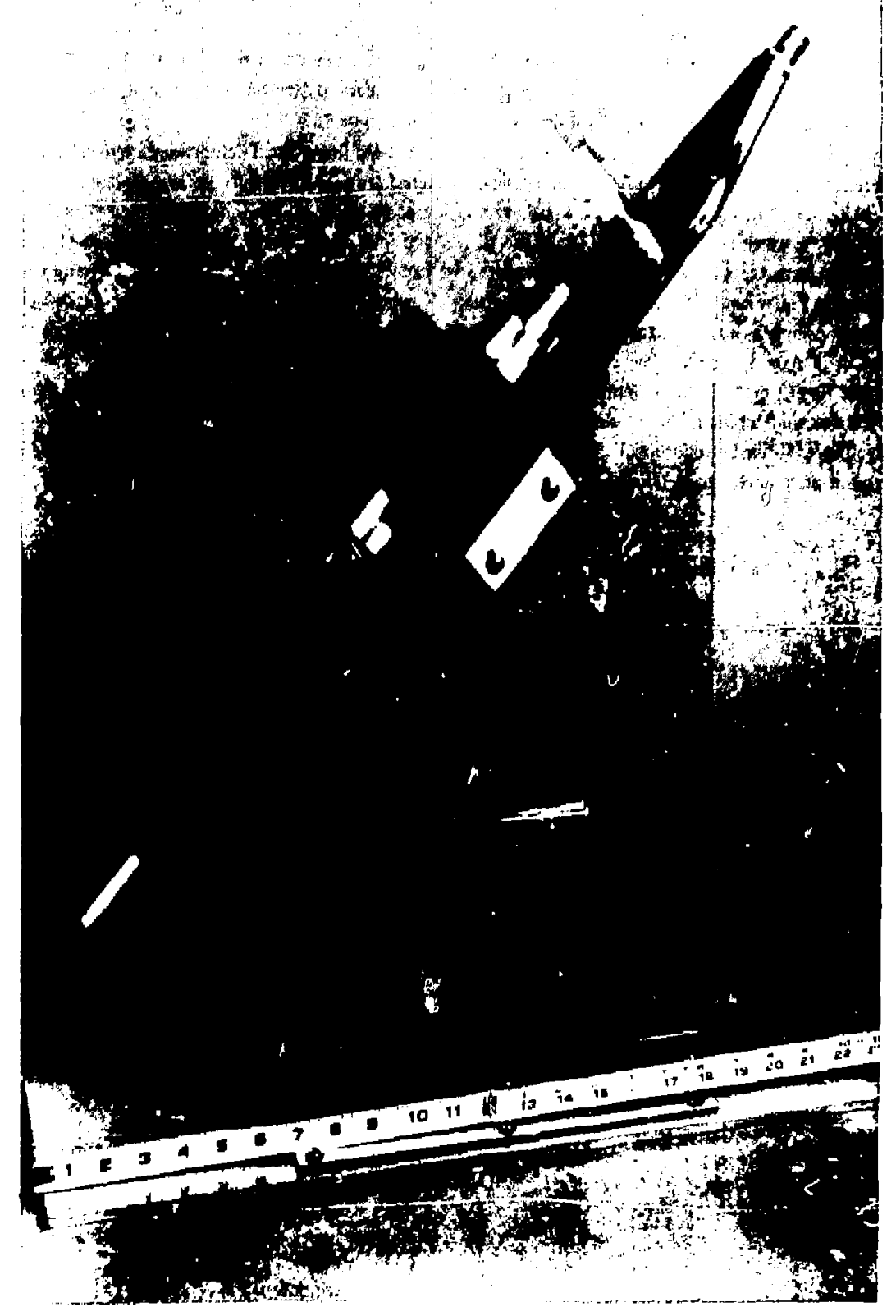

FII;. 5. Overall view of the XRFA flume and detector assembly. 


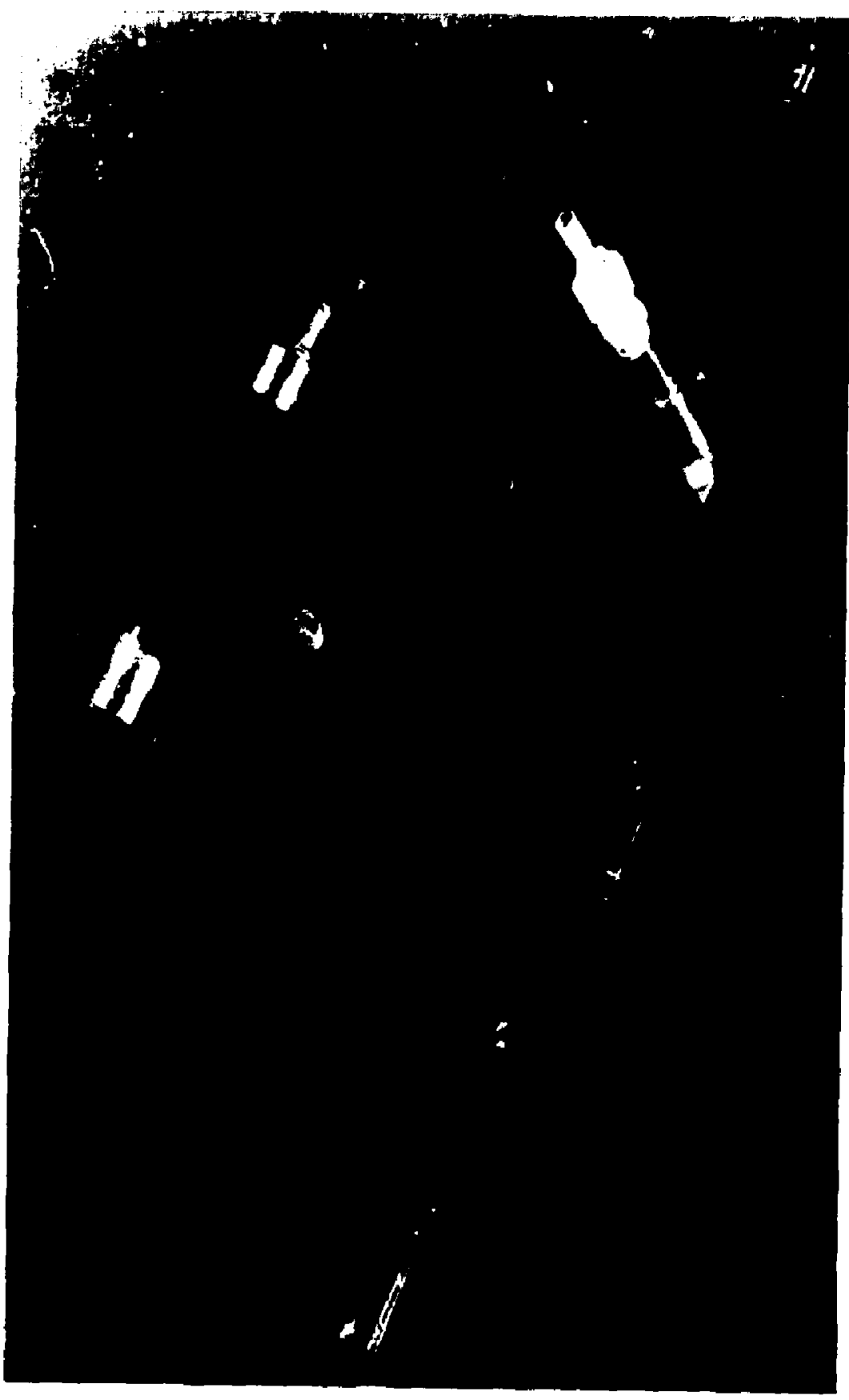

FIG. 6. The XRFA thume and detector assembly with covers installed. 


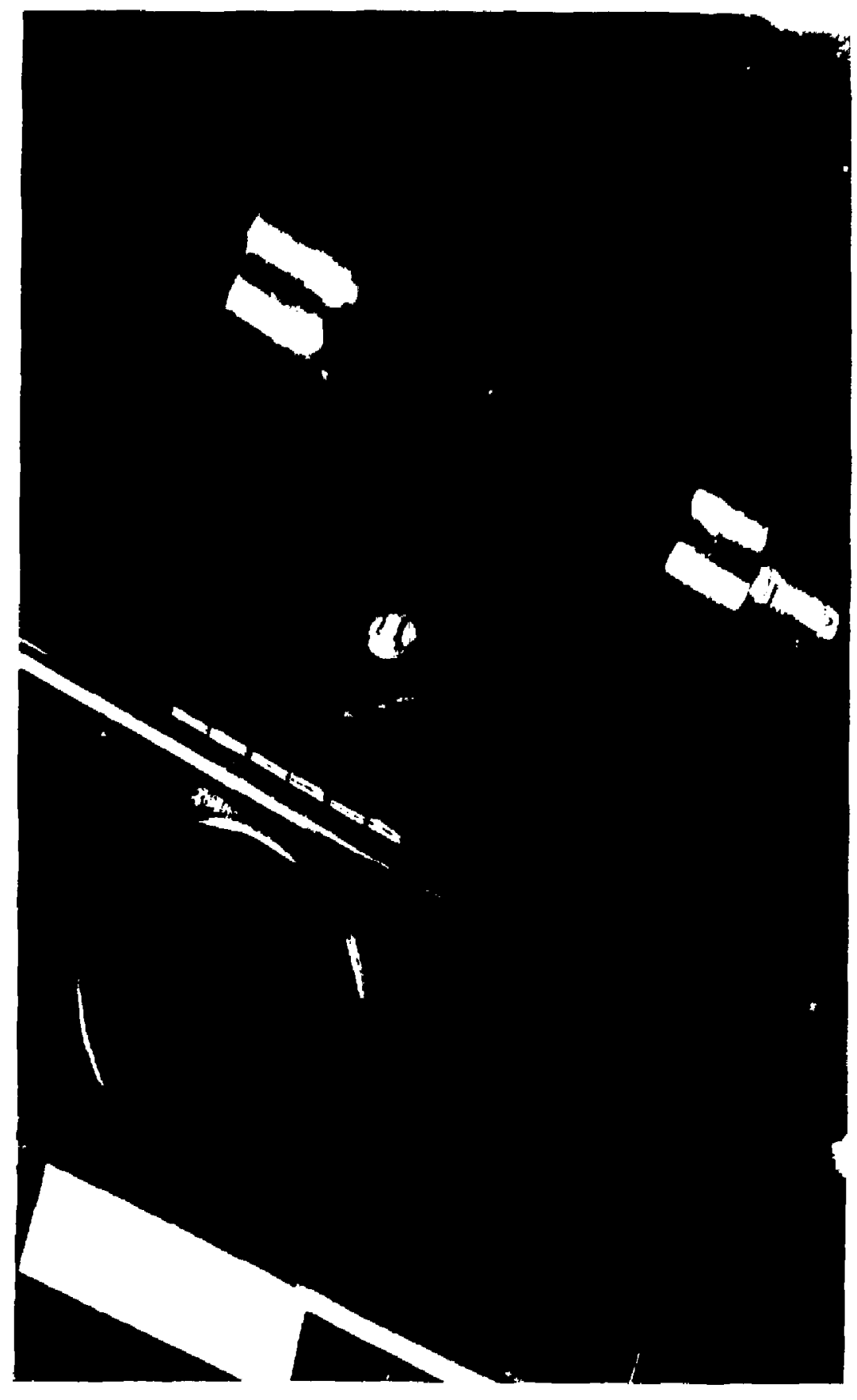

HIC. 7. Cloweup of the XRFA source-detector and window. 
sample thicknese changess, dead time lossctio anj imen" walceraty. The ratios for a "hlank" sample idvilled wastert. sored in the progeram. ars suthIf scled and the net vental, if ally, is compined with the valodird devation (o) elf the blank spectrum. If Whe net regend is lese than 3 ar abose the blank, no ate-

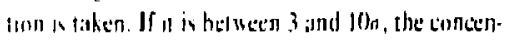

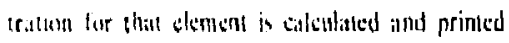

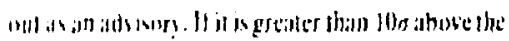
blath, ihe dlarm toreuit is astivated is sell. Afler

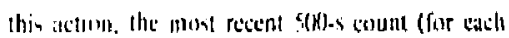

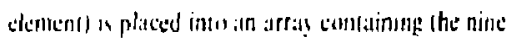

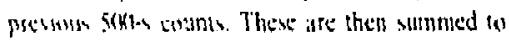

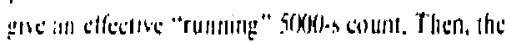

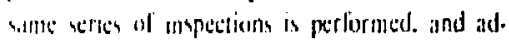
114010 of alarms ate initiated from the running tatsl dittil. The dual register system allows both a

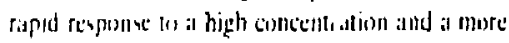

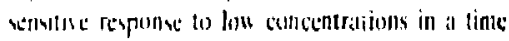
frinhe I0 lunes buger. The times, inctentally.

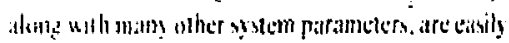
changed hy telets ne inpuls to the proteram. Dat a alsyuristan and timing are accomplisticd with wembly litnglage interrupt routines: datite h. ndling reutines are writen in FORTKAN for tals! madificallion.

Results. We tallihrated the instrumem in the lahoralkety using standard solutions of cich metal Ihis! ranged from $60 \mathrm{lo} 11 \times 00 \mathrm{ppm}$. The solutions were recirculated through the nume, and data nats collected fos al leats 5000 s per run. The calibration curves stius oblained (F. E) were stored in the microprocessor, From these data, we calculated semsitivitics and minimuste deteclable concentranoms bor the th alcments of metesi. The figures.

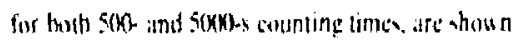
ii) Tilhlu 7 .

Tible shous the 6.l.l. maxumum peranissibic

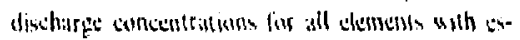
liblished limils, If uc compare fahlew 7 and $\mathrm{X}$. WE find that. at maximum jormmshle sollemerition.

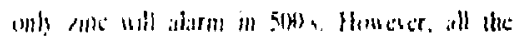

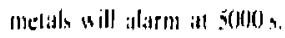

it shouts be noted that semstiving changes

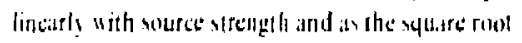

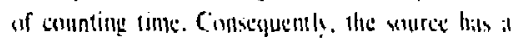

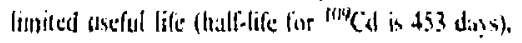

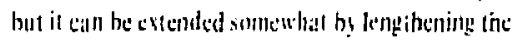
counting periods. The source a nearing the end of its life now; seplitement w:ll be recuired in inprox. imalcly 6 memthis.

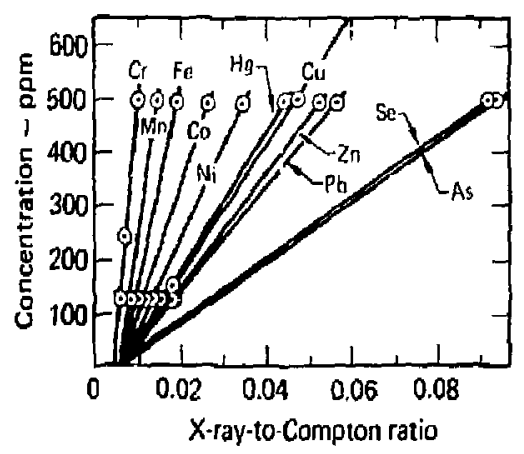

FIG. 8. Calibration curves qùtained with the XRFA monitor.

Table 7. Minimum detectable and alam kevels for the XRFA monitor.

\begin{tabular}{|c|c|c|c|c|}
\hline \multirow[b]{2}{*}{ Hement } & \multicolumn{2}{|c|}{ so0-s coesnting time } & \multicolumn{2}{|c|}{5000 s counting time } \\
\hline & $\begin{array}{l}\text { Minimum detectable } \\
\text { (3a above bln }) \text {, DPm }\end{array}$ & $\underset{(100), \mathrm{ppm}}{\text { Namm }}$ & $\begin{array}{l}\text { Minimum detcetable } \\
\text { (30), ppm }\end{array}$ & $\begin{array}{c}\text { Alarm } \\
\left(10_{0}\right), \mathrm{ppm}\end{array}$ \\
\hline $\mathrm{Cr}$ & 35.6 & 118.7 & 11.2 & 37.3 \\
\hline$M_{n}$ & 23.4 & 78.0 & 7.4 & 24.7 \\
\hline $\mathrm{Fe}$ & 14.9 & 49.7 & 4.7 & 15.7 \\
\hline$C_{0}$ & 9.8 & 32.6 & 3.1 & 10.3 \\
\hline $\mathrm{N}$ & 6.3 & 21.0 & 2.0 & 6.7 \\
\hline au & 4.9 & 16.3 & 1.6 & 5.3 \\
\hline$z_{n}$ & 4.1 & 13,7 & 1.3 & 4.3 \\
\hline As & 2.2 & 7.3 & 0.7 & 2.3 \\
\hline se & 22 & 7.3 & 0.7 & 2.3 \\
\hline $\mathbf{H}_{8}$ & 5.0 & 16.7 & 1,6 & 5.3 \\
\hline $\mathrm{Ph}$ & 3,6 & 120 & 1.1 & 3.7 \\
\hline
\end{tabular}


Table 8. LLL maximusn permissible discharge concen. trations for metals in sewage.

\begin{tabular}{cc}
\hline Mctul & $\begin{array}{c}\text { Moximum petmisible discharge } \\
\text { concentration, ppm }\end{array}$ \\
\hline $\mathrm{Cr}$ & 100 \\
$\mathrm{CH}$ & 10 \\
$\mathrm{Zn}$ & 50 \\
$\mathrm{Ni}$ & 10 \\
Cismbinalions & Tolat $<100$ \\
\hline
\end{tabular}

Problems. In arder to provide the thin sample alyer, the simple anst be free of large particulates. Hic purchissed a 1-J/2 BH] macerator allegedly capahle of grinding any solids to $<100-\mu \mathrm{m}$ diam. This unit has given us a great dat of trouble: it hecomes clogeted with the very materiaks it is suppowed to grind. Currently we are redesigning the plumbing with the hope of removing this problem.

Future Plans, The system has been instilifed online. and with the excisption of the plugging problem, seenss to be opteruting propterly. We platl to ginher dala and experience for weeks or even months before hooking op the alarm circuits; nunkerous false alarms cend to generatt a credibility tap among operational personthet that is difficalt to cradicale? We anticipate that ninor software changes will be required and that ather plumbung prohlems will arise. If all goes will with this installa. tion, an even more sensitive system urilizing a gats scintillation proportional detector ${ }^{*}$ will be considered.

$$
\text { Not huilt : }
$$

\section{INDUSTRIAL HYGIENE}

\section{Fire Environmental Tests for Self-Contained Breathing Apparatus}

We are concerned that Nalional Institute for Occupational Salety and Hualth Certificuion tests for self-contiined breathing apparatus (SCBA) do not adequatsly cviluate the performance of SCBA under fire conditions. We know that the strironment to which a fire fighter and his equipment ate exposed is the restilt of muny variables such as high air temperature, high humidily, witer droplets in the ajr, steim, fire decomposinion products, fiteextinguishing ugents, and radiant heal. We think a firu fighter's protective gear should not only give him the protection he necds for halardous work, hilf also should provide added protection in the tise of urforeseen emergencies sech as flareups.

Wo cenlered ous studies on evalusting existing tequipment so SCBA could be selected from devices that offer the best protection against conditions that could exist during a fire at the Laboratory. Busust if liturafure search revealed very little information on such evaluations, we developed lest paranielers and eriteria to evaluale varjods mak ts and models of SCBA.

The resultis of our subjective tests to high and law air kemperatures, our instrume sed tests to high and low air lomperatures, and our thermal shock losts have all heen nublished previously. 3.5 This reporl coveres the results of the moisture lest.

Paramesers and Fayipmen for Mnisture Tests. The wille present at a fire secne mely he in various forms-rfom a fine mist similar lis water from s hose norkle overspray bo a deloge of run-off water from an upper kevel. A fine mist woukl atppeat to ereale only visual problems. However, lisect volumes of watter might inlerfere with the uptralion of SCBA. To determine what effecls jarge volumes of waler would have on the operational chasacleristics of SCBA, we tester various mates or models of SCBA benealth a laree shower hetod. A solenoid was placed in the wherline lo provide ath instiant on or off. We tested two of eitch makt of model of SCBA, all of which werc either new or maintained in top tondition by manulacturer certified personnel. The facepicce for each SCBA was mounted on a dummy head; the entire SCBA was then connected to the LLL mechanical hreathing machine located outside the shemer chanber. The breathing mathint was set on a noderate to healyy work ritte of 52.5 I of air/ min to simulate a fite fighter al work. The difference between atmospheric and imernal facepiect pressure wass measured with as sulihritcd pressure Iransubecer and monilored on as strip-chart recorder.

The SCBA unit, including the filcupiese, was thoroughly inspected and tesked for keaks before we sel it up in the shower chamber. We uperaled it for I min 10 ctsiure that it was working properly and to medsure its normil operating pressures. The shower was then turned on and the SCBA was deluged with water (Fig. 9). The unit was exposed to this water flow for the length of time it took to empty the air cylinder. The wotal operating time and the time at which the low air pressurt alarm wenl off were nolst. 


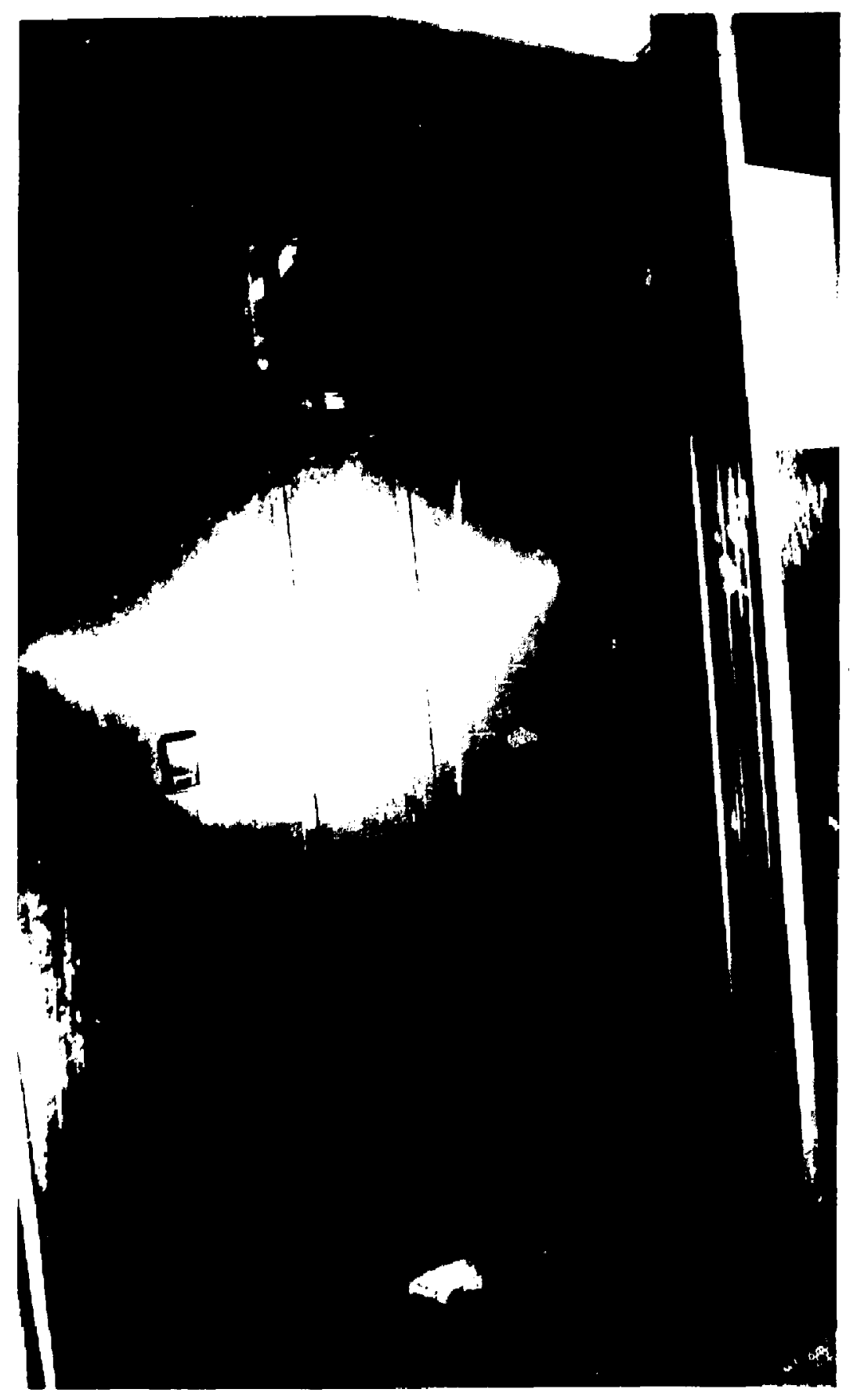

FIC. 9. Mloisture test selup for SCBA. The breathing machine was lacated outside the test chamber. 
Table 9. Moisture test for pressure-demand SCBA.

\begin{tabular}{|c|c|c|c|c|}
\hline \multirow{2}{*}{$\begin{array}{l}\text { Make of } \\
\text { SCBA }\end{array}$} & \multicolumn{2}{|c|}{$\begin{array}{l}\text { Facepiece pressure } \\
\text { before thower. } \\
\qquad \mathrm{H}_{2} \mathrm{O}^{\circ}\end{array}$} & \multicolumn{2}{|c|}{$\begin{array}{l}\text { Panepiece presure } \\
\text { diritigg dower, } \\
\mathrm{H}_{2} \mathrm{O}^{\prime \prime}\end{array}$} \\
\hline & Inhalation & Exhalation & Inhalation & Exhabtio \\
\hline Globe & 0.10 & 1.21 & 0.10 & 1.20 \\
\hline MSA & 0.00 & 1,95 & 0.00 & 1.95 \\
\hline Scrott 6000 & -0.20 & 2.46 & $=0.20$ & 2.46 \\
\hline Swoll 9000 & 0.80 & 2.39 & 0.80 & 2.39 \\
\hline Scost 4.5 & 0.13 & 1.76 & 0.13 & 1.76 \\
\hline Survivait & 0.20 & 1.80 & 0.20 & 1.80 \\
\hline
\end{tabular}

Test Results. Two each of the following makes and models were tested under the water stream:

- Scolt 6000

- Scoti 9000

- Scotl 4.5

- Glube Guardsman

- MSA 401

- Survivair

The operational chatracteristics of all units tested scre unaflected by the large amount of water, as shown in Tuble 9 .

\section{INSTRUMENT DEVELOPMENT}

\section{Uevelopmewts in Neutron Spectrometry}

A program to develop neutron spectrometry systems for radjation protection meisurements has existed in Hazards Control for several years, 6.14 This effort resulted in the system described by Slaghter et al. ${ }^{15}$ Recently the emphasis of the program has shifted lowards optimizing the operating parameters of the system and improving our dat a reduction technigues. Thus, in this report, we brielly discuss (1) the energy range required for neutron sfectroscopy measurements used in rudiation protection, (2) the means of estimating the resolution requised. (3) some advances in pulseshape discrimination, (4) the light oulput of the NE213 organic liquid scintillator for protons near $1 \mathrm{MeV}_{\mathrm{t}}$ and (5) the means of estimuting a proportional counter's sesponse to neutrons with energies greater than its upper detection limit,

Exergy Rere. Neutron spectrosco, has many applications in fadiation prolection. W. sc it (1) to obtain informetion for correcting the response of dosimeters; (2) to provide data for shielding calcula- lions and to delernine the efticacy of shieds; (3) to make direct measurements of Josimetric quankilies, particularly in regions poorly covered by existing dosimeters; and (4) to characterize calibration sources.

Although we can measure the neulion energy specirum from a few kiloetectron volts to several tens of megatectson volts by using a combination of detectors, ${ }^{16-18}$ we find that the aciual energy range may be considerably less. Thus, to determine what energy range to consider, we ascume that, for radiation protection purposes, an adequate measurement of the neutron specirum is one for which neither the nculions below the low-energy limit nor those above the high-energy limit produce more than 5 of of the lotal dose equivalent.

Based on this assumption. we calculated the encrgies bulow which 5 and $95 \%$ of the colal dose equivalent occursed for 121 of the neutron spectra conpiled by Ing and Makra. ${ }^{19}$ The cases considered were the ${ }^{235} U$ Maxwellian and Cranberg fission speelsa; the Jerebel, Godjva IV, and Flattop critical issemblies; the HPRR, VIPER, and IBR reactors: homogenteus $\mathrm{H}_{2} \mathrm{O}$ and $\mathrm{D}_{2} \mathrm{O}$ 㑊sile solutions: and the Crunberg spectrum transporled through $\mathrm{H}_{2} \mathrm{O}$, $\mathrm{D}_{2} \mathrm{O}$, concrete, $\mathrm{Fe}, \mathrm{Cu}, \mathrm{Pb}$, and ${ }^{29 \mathrm{U}} \mathrm{U}$. Also considered were $\mathrm{H}_{2} \mathrm{O}$ and $\mathrm{D}_{2} \mathrm{O}$ moderaled spectra Iransporled through conercte, $\mathrm{Fe}, \mathrm{Cu}$, and $\mathrm{Pb}$; and 14.6-McV neutrons trunsported through concrele, $\mathrm{Fe}, \mathrm{Cu}, \mathrm{Pb}$, and ${ }^{238} \mathrm{U}$. The factors required to convert the neutron spect ra to dost-equivalent spectra were obtained by linear interpolation between the maximum dose-equivalent-per-neutron-fluence values given by Auxier et al. ${ }^{20}$

The results of the calculations are summarized in Table 10, which shows the percentages of spectra requiring meusurements below some typical lowenergy thresholds. The majority of the spectra, even those from 14.6-MeV neutrons, require mealsurements below $500 \mathrm{keV}$, which is often the practical lower limit for measurements taken with organic

Table 10. The percentage of neulron spectra requiring mesurements below the given threshold energies.

\begin{tabular}{cccc}
\hline $\begin{array}{c}\text { Threshold, } \\
\text { keV }\end{array}$ & $\begin{array}{c}\text { Fission } \\
\text { neutrons, } 7\end{array}$ & $\begin{array}{c}\text { 14.6-Mev } \\
\text { nevtrons, } z\end{array}$ & Total, z \\
\hline 10 & 26.4 & 3.3 & 20.7 \\
50 & 39.6 & 3.3 & 30.6 \\
100 & 49.5 & 13.3 & 40.5 \\
500 & 100.0 & 56.6 & 89.3 \\
\hline
\end{tabular}


scintillators. Upper energy limits are shown in Tible 11, which gives the percentuge; of spectra rcquiring matsurements above various high-energy limits. As expected. most spectra produced by 14.6MeV neutrons require measurements above $10 \mathrm{MeV}$ (actually $14 \mathrm{MeV}$ ), but only a few of the fission neutron spectra need go above? MeV. Being able to limit the dyaumic range is of considerable practical valus:

Medsuring neutron spectra below $10 \mathrm{kcV}$ is too difficult to allempt routinely for radiation prolcction purposes. However, the dose equivalent per neutron flucence varies so lj!tle below $10 \mathrm{keV}$ thet detailed neutran spectra in this region maly not be necessary. If we alsume no measurements will be made below $10 \mathrm{keV}$, we tain reconsider the usefulness of making measurements below $50 \mathrm{keV}$. Since only 13.2\% of the fission spectra and none of the 14.6-MeV spect ra require threstiolds between 10 and $50 \mathrm{keV}$, il is nol unreasonable to place the lower limil for practical measurements at $50 \mathrm{keV}$. Of coursc, some radiatian-protection applications of neutron spectroscopy will tequire brouder entrgy limits thin those suggested by these results, and other input spectra, for eximple, 2.5-McV neutrons from the $\mathrm{D}(\mathrm{d}, n)^{3} \mathrm{He}$ reaction, could modify the conclusiuns.

Resolution. The results just presented were bused on the dose-esjuivalent sptetpun. We also estublished the resolution for neutron spectroscopy measurements based on this spectrum. We assumed that we needed tite best dita where the dose equivilent per neutron lluence chinged the most rapidyly is a function of energy. (A fluence matsurement is adequate for regions where the conversion fictor does not wory.) Thraefore, we culculated the necessiry energy intervals hetween $10 \mathrm{keV}$ and $20 \mathrm{MeV}$ to ensure that the dose conversion factors would always be within $10 \%$ of the published valuss, 211 The results, given in Tahle 12, show that a

Table 11. The percentage of neutron spectra requiring measurements above the given upper energy limits.

\begin{tabular}{cccc}
\hline $\begin{array}{c}\text { Uppcs unetgy } \\
\text { Limit, McV }\end{array}$ & $\begin{array}{c}\text { Fission } \\
\text { neutrons, \% }\end{array}$ & $\begin{array}{c}\text { 14.5-MeV } \\
\text { neutrons, } z\end{array}$ & Total, \% \\
\hline 5 & 45.1 & 86.7 & 55.4 \\
6 & 5.5 & 86.7 & 25.6 \\
7 & 2.2 & 86.7 & 23.1 \\
8 & 1.1 & 86.7 & 22.3 \\
10 & 0 & 86.7 & 21.5 \\
\hline
\end{tabular}

resolution on the order of $20 \%$ was sufficient over most of the encrgy runge.

Pulsc-Shape Discrimination. Neutron spectroscopy detectors, e.E., proportional counters filled with hydrocarbon gas and organic scintillators, usually require discrimincion circuits that reject unwanted gammi-ray pulscs on the basis of the pulse shuje. The pulsenshape discrimination (PSD) circuit we ure presently using ${ }^{15}$ is a modern version of the zero-cross timing cirruit described by Alexander and Coulding. "I It has a wide dynamic range and can handle high counting rutes but is limited in its low-energy response. Thus, we hive studied a number of PSD circuits with the purpose of developing one that will provide an oplimum lowenergy response for an organic scintillator.

An alternative to the zero-cross timing circuit is the tharge comparison circuil described by Gatti and de Martini.22 This circuit compares the cherge in the exrly part of the pulse with that in the late part by using a linear filler. It is also possible to

Table 12. Minimum number of energy intervals for dose-equivajent-per-fluence values to be within $10 \%$ of the published values.

\begin{tabular}{|c|c|c|c|}
\hline $\begin{array}{l}\text { Energy range, } \\
\text { Mcy }\end{array}$ & $\begin{array}{l}\text { Dosece equivalent } \\
\text { per fuence }\end{array}$ & $200 x$ & $\left(\frac{E_{2}-E_{1}}{\overline{E_{2}}+\overline{E_{1}}}\right)$ \\
\hline $0.010-0.015$ & 11.9 & & 40.0 \\
\hline $0.015-0.022$ & 14.4 & & 37.8 \\
\hline $0.022-0,029$ & 17.3 & & 27.5 \\
\hline $0.029-0,039$ & 20.9 & & 29.4 \\
\hline $0.039-0.050$ & 25.2 & & 24.7 \\
\hline $0.050-0.064$ & 30.5 & & 24.6 \\
\hline $0.064=0.080$ & 36.8 & & 22.2 \\
\hline $0.080-0.10$ & 44.4 & & 22.2 \\
\hline $0.10-0.13$ & 53.8 & & 26.1 \\
\hline $0.13-0.17$ & 65,2 & & 26.7 \\
\hline $0.17-0.21$ & 79.2 & & 21.1 \\
\hline $0.21-0.26$ & 9.1 & & 21.3 \\
\hline $0.26-0.33$ & 117 & & 23.7 \\
\hline $0.33-0.41$ & 142 & & 21.6 \\
\hline $0.41-0.50$ & 172 & & 19.8 \\
\hline $0.50-0.64$ & 207 & & 24. \\
\hline $0.64=0.80$ & 249 & & 22.2 \\
\hline $0.80-1.0$ & 299 & & 22.2 \\
\hline $1.0=2.5$ & 338 & & 85.7 \\
\hline $2.5-4,0$ & 377 & & 46.2 \\
\hline $4.0-10.0$ & 422 & & 85.7 \\
\hline $10.0-120$ & 477 & & 18.2 \\
\hline $12,0-14,0$ & 569 & & 15.4 \\
\hline $14.0-20,0$ & 624 & & 35.3 \\
\hline
\end{tabular}


make the comparison by forming a ratio ${ }^{23}$ Sabbah and Suhami ${ }^{24}$ have shown that a charge comparison circuit gives a better low-energy response than a zero-cross timing circuit.

Using the data of Kuch,ir and Lynch, ${ }^{25}$ we compared the relative variance of the differences in neulron and gamma-ray pulses produced by linear fillers and fatio measutements. We obtained 4.0 for linear fillers and 6.2 for ratio measurements. Based on these results, we have directed our efforts towards designing a circuit that is similar to Sabbah and Suhami's chirge conparison circuit ${ }^{24}$ but that inore cosculy approximates Gatui and de Martini's optimum filter.?2

Light Output. The NE213 liquid oryanic scintillalor (Nuclear Enterprists, Inc., San Cirlos, Calif.) is widely used lor fast-neutron spectrostopy. In this scintillator neutrons are measured via the lighe produced by recoil protons. Unforiunately, the relationship belween the deposiled proton encrgy and the light output is complicated. A number of people have measured this relationsltip and have obtifned a wide variecty of results. ${ }^{26}$ However, since the datid of Verbinski of al. ${ }^{27}$ cover the grealest unergy ranges. they are gurkings the mast widely used.

We calibrate the pulsitheight of the spt:tronicter using Compton recoil electrons produced by a gaimma-ray source such as ${ }^{22} \mathrm{~N}_{3}$; bence, it is uselut to relate the proton encrgies to the slectron energies that nroduce the same light outpul in the scintillator. The data of Verbinski er al. allow us to do this beciuse of the assumplion that the light outpul, as a function of electron conergy, is linear with a te, 0 intercept. Other data ${ }^{20}$ show that the light output is a linstar funclion of electron energy but that zero light outpul oceurs at a nonzero clectron energy.

We have studied this problem by measuring the response of an NE213 scintillator $(2.54 \mathrm{~cm}$ in diameles by $2.54 \mathrm{~cm}$ in heighi) 10 gamma rays from ${ }^{241} \mathrm{Am},{ }^{57} \mathrm{Co},{ }^{22} \mathrm{Na},{ }^{137} \mathrm{Cs}$, and ${ }^{54} \mathrm{Mn}$. The $60-\mathrm{keV}$ gamma ray from ${ }^{24}$ Am produces a total energy peak in the scintijlator. For the otber sources, the balf-heights of the Compton electron distributions were found and filled with is linear function of energy bused on the maximum values for the Compton recoil electrons. A straigh line fin the dato to within $0.3 \%$ for all of the points, which illustrates the linearity of the light output us a funetion of electron energy; the intercepl, however, was definitely nonzero. Using the light units defined by Verbinski et al,", we found that electron energy $\left(E_{c}\right)=14.1 \mathrm{keV}$ $+1171,6 \mathrm{keV} /$ light unit. The data of Verbinski et al, are plotled in Fig. 10 as proton energy vs electron cnergy for the assumptions $\mathrm{E}_{e}(0)=0$ and $\mathrm{E}_{\tau}(0)$ $=14.1$.

These data, and their first and second derivatives, play an importunt part in reducing the recorded pulse-herght spectrum to a neutron spectrum. ${ }^{15}$ The response function uscd has its major effect on the reduced data for neutron energies of I MeV and lowcr. This problem is imperlam ensugh to require further determinations of $E_{p}$ vs $E^{\prime \prime}$

A Proportional Counter's Response to HighEnergy Neutrons. As we have shown above, most neulron spectra require measurements at encrgies below the lower detection limil of an organic scintillator. A hydrogen-filled proportional counter can be used to measure neutrons at these low energies, ${ }^{16}$ but a problem occurs when there are neutrons present that produce recoil protons with ranges that ex. ceed the dimensions of the counter: these recoil protons produce a pulse-height spectrum that must be subtracted before the data can be reduce 1 to a neutron spectrum. In the pilst we used a para netric prosedur ${ }^{15}$ wo determine this pulse-height speetrum, but it was nol completely sutisfactory. As a result, we develoned a Monlc Carlo procedure similar to that described by Bunjamin. ${ }^{\text {th }}$

In our program random numbers choose (I) where the $n, p$ seultering event will oceur in the counter and (2) the energy and direction of the recoil proton. A geometrical cilculation deturmines

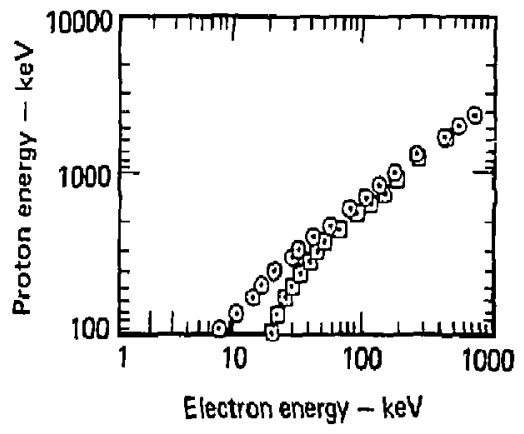

FIG. I0. Proton energies and electron energies producing the sume light output $(\mathrm{L})$ in the scintillator plotted for the data of Verbinski et al. $\odot$, $(L=0)=0 \mathrm{keV} ; \mathrm{Q},(L=0)=14.1 \mathrm{keV}$. 
the distunce from the point of interaction to the rearest counter wall, in the difection the proton is going. The proton range vs energy, a relation ob. lained by inegrating the stopping cross sections given by Andersen and Ziegler, ${ }^{29}$ decermines the trtergy deposited by the proton.

The progrum alsisutes that the counter has a windrical getometry, hut it maly have any dimen. sions and may be filled wilk any hydrogenous gas or gas mixlure. . Nthough the program can assume an isthlepic irradiation of the counter, it normally assumes a plane heam, which may be incident on the counter at any angle.
If we ignore multiple scattering and keep the energy-loss calculations as simple as pewsible, the prograra will run on a smali computer. A veeover, it will run rapidly enough to handle seve- 11 thousand cases per hull-hour, which is comparatit to the time required to obtain satisfactory datid with the proportional tounter. Our lests ind icate good agrecment belwect measured and culculater tesponses to monoentergetic neutrons both within and above the energy limit of the counter. We have also determined that, with smoothing, retatively few $\left(10^{4}\right)$ cases provide a back ground of sufficienc quality for our datia reduttion lechniques. Using a small computer visy make it possible 10 apply these tecitniques to a portable spectrometer.

\section{TECHNICAL NOTES}

\section{RADIATION PROTECTION}

\section{Intermediate Energy X-Ray Spectra for General Shielding Calculations}

Recent efforts to perform skyshine calculations For stindind $x$-ray units have resulted in the development of al sel of intermediute energy (0.5-10 MeV) x-ray speetra ${ }^{*}$ (Figs, 11-16) from a number of literature souress. ${ }^{3(1)-40}$ These are summarised in a form convenient for input to the LLL version of the MORSE code transporl code

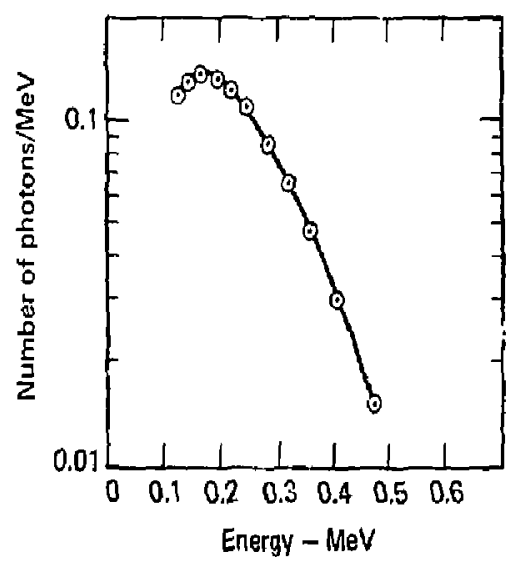

FIG. 11. The 0.5*MeV x-ray spectum.

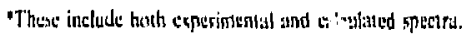

(Tubles 13-18). Each spectrum is gencraily at numerical aluerage of the spectral found in the relerences noted. A thick tungsten targer was issumed, alone with same beam fill ration. The electron polential $: \cdot ;$ included for tach table and figure.

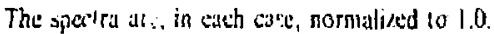

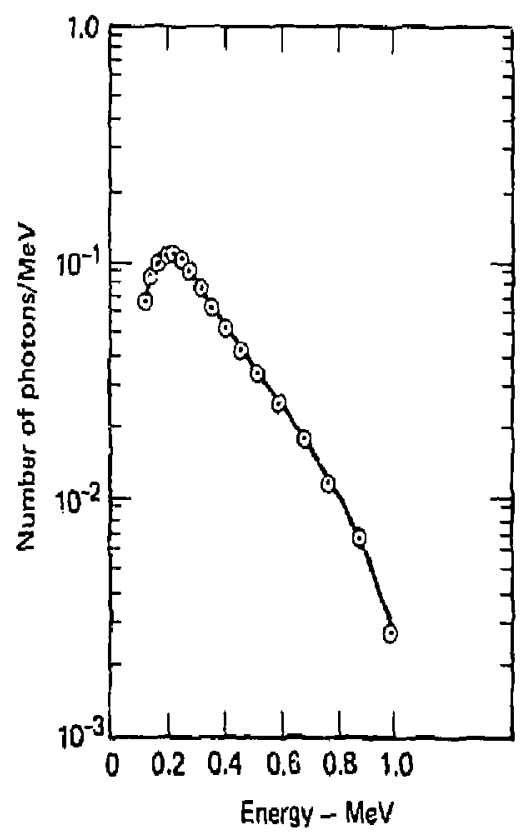

FIG. 12. The 1.0-MeV $x$-ray spectrum. 
In the absence of specific specira, these should provide guidance for initial rediation shielding and scatter estimates in the middle entrgy range.

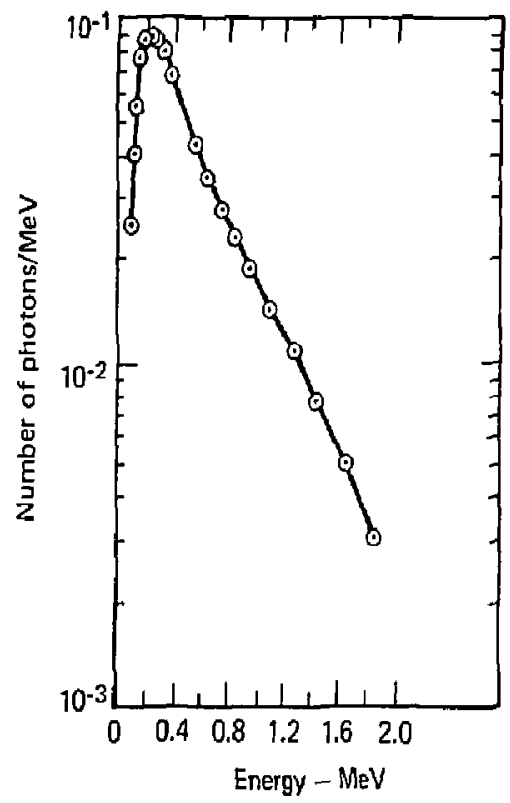

FIG. 13, The $2.0-\mathrm{MeV} x$-ray spectrum.

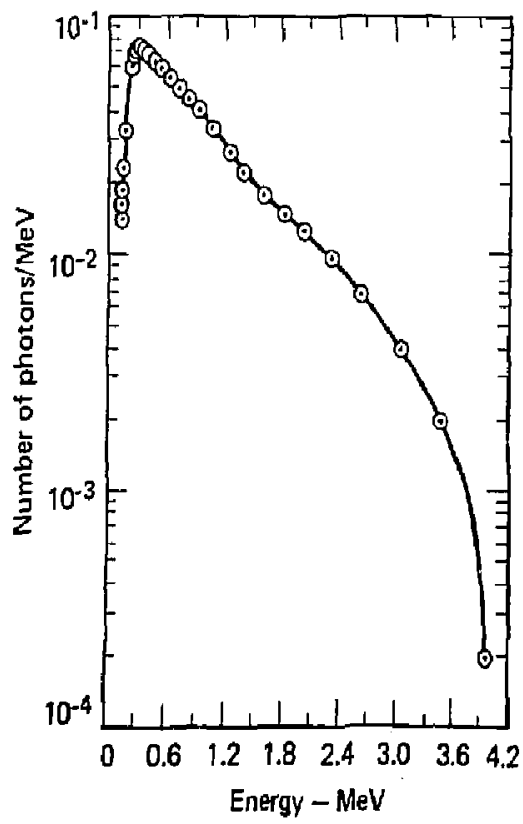

FIG. 14. The 4,0-MeV x-ray spectrum.

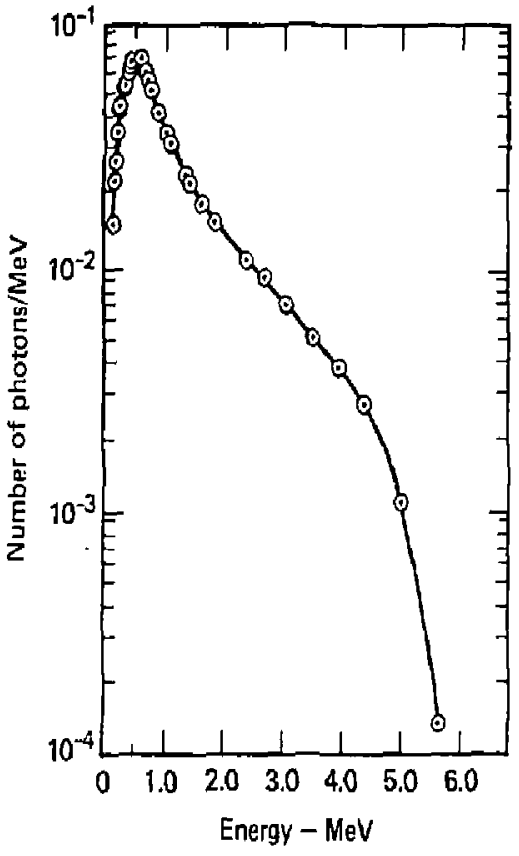

FiG. 15. The 6.0-MeV x-ray spectrum.

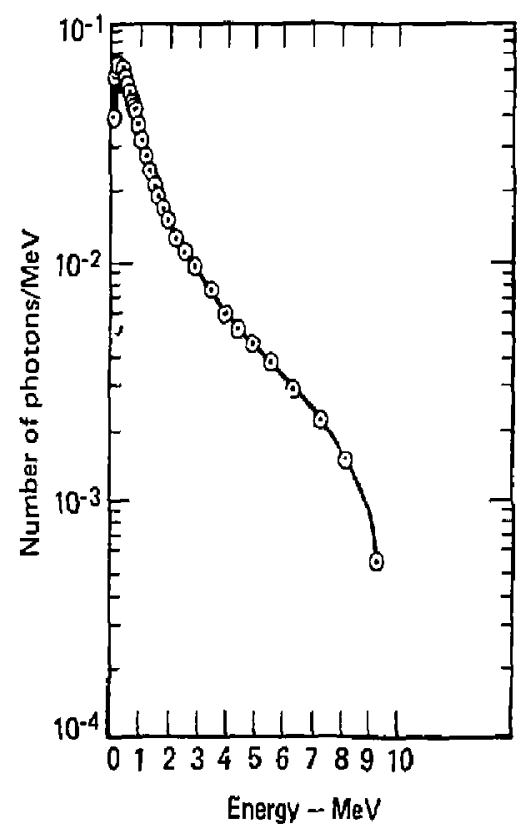

FIG, I6, The 10,0-MeV x-ray spectrum. 
Table 13. The 0.5-MeV maximum potential $x$-ray spectrum. ${ }^{30-32}$

\begin{tabular}{cccc}
\hline $\begin{array}{c}\text { MORSE 76L } \\
\text { goup number }\end{array}$ & $\begin{array}{c}\text { Averges } \\
\text { enctgy, MeV }\end{array}$ & $\begin{array}{c}\text { Number of } \\
\text { photons/goup }\end{array}$ & $\begin{array}{c}\text { Number of } \\
\text { pholons/MeV }\end{array}$ \\
\hline $1-24$ & - & 0 & 0 \\
25 & 0.464 & $3.23 \times 10^{-2}$ & $1.54 \times 10^{-2}$ \\
26 & 0.411 & $5.54 \times 10^{-2}$ & $2.99 \times 10^{-2}$ \\
27 & 0.362 & $7.81 \times 10^{-2}$ & $4.77 \times 10^{-2}$ \\
28 & 0.320 & $9.72 \times 10^{-2}$ & $6.74 \times 10^{-2}$ \\
29 & 0.282 & $1.09 \times 10^{-1}$ & $8.52 \times 10^{-2}$ \\
30 & 0.249 & $1.21 \times 10^{-1}$ & $1.08 \times 10^{-1}$ \\
31 & 0.220 & $1.22 \times 10^{-1}$ & $1.23 \times 10^{-1}$ \\
32 & 0.194 & $1.16 \times 10^{-1}$ & $1.32 \times 10^{-1}$ \\
33 & 0.171 & $1.06 \times 10^{-1}$ & $1.38 \times 10^{-1}$ \\
34 & 0.151 & $9.32 \times 10^{-2}$ & $1.37 \times 10^{-1}$ \\
35 & 0.133 & $7.09 \times 10^{-2}$ & $1.18 \times 10^{-1}$ \\
\hline
\end{tabular}

Table 15. The 2.0-MeV maximum potential $x$-ray spectrum. $32-35$

\begin{tabular}{|c|c|c|c|}
\hline $\begin{array}{l}\text { MORSE } 76 \mathrm{~L} \\
\text { goup numbes }\end{array}$ & $\begin{array}{c}\text { Average } \\
\text { encrgy. Mov }\end{array}$ & $\begin{array}{l}\text { number of } \\
\text { phutons/group }\end{array}$ & $\begin{array}{l}\text { Number of } \\
\text { plotons/McV }\end{array}$ \\
\hline $1-13$ & - & 0 & 0 \\
\hline $\begin{array}{l}14 \\
15 \\
16 \\
17\end{array}$ & $\begin{array}{l}1.84 \\
1.63 \\
1.44 \\
1.27\end{array}$ & $\begin{array}{l}1.40 \times 10^{-2} \\
2.05 \times 10^{-2} \\
2.71 \times 10^{-2} \\
3.42 \times 10^{-2}\end{array}$ & $\begin{array}{l}3.06 \times 10^{-3} \\
5.12 \times 10^{-3} \\
7.64 \times 10^{-3} \\
1.09 \times 10^{-2}\end{array}$ \\
\hline $\begin{array}{l}18 \\
19 \\
20 \\
21\end{array}$ & $\begin{array}{l}1.12 \\
0.986 \\
0.870 \\
0.768\end{array}$ & $\begin{array}{l}3.93 \times 10^{-2} \\
4.54 \times 10^{-2} \\
4.86 \times 10^{-2} \\
5.29 \times 10^{-2}\end{array}$ & $\begin{array}{l}1.42 \times 10^{-2} \\
1.86 \times 10^{-2} \\
2.26 \times 10^{-2} \\
2.78 \times 10^{-2}\end{array}$ \\
\hline $\begin{array}{l}22 \\
23 \\
24 \\
25\end{array}$ & $\begin{array}{l}0.678 \\
0.598 \\
0.528 \\
0.465\end{array}$ & $\begin{array}{l}5.79 \times 10^{-2} \\
6.38 \times 10^{-2} \\
6.68 \times 10^{-2} \\
7.03 \times 10^{-2}\end{array}$ & $\begin{array}{l}3.46 \times 10^{-2} \\
4.31 \times 10^{-2} \\
5.12 \times 10^{-2} \\
6.10 \times 10^{-2}\end{array}$ \\
\hline $\begin{array}{l}26 \\
27 \\
28 \\
29\end{array}$ & $\begin{array}{l}0.411 \\
0.362 \\
0.320 \\
0.282\end{array}$ & $\begin{array}{l}7.05 \times 10^{-2} \\
3.15 \times 10^{-2} \\
6.76 \times 10^{-2} \\
6.22 \times 10^{-2}\end{array}$ & $\begin{array}{l}6.94 \times 10^{-2} \\
7.97 \times 10^{-2} \\
8.56 \times 10^{-2} \\
8.91 \times 10^{-2}\end{array}$ \\
\hline $\begin{array}{l}30 \\
31 \\
32 \\
33\end{array}$ & $\begin{array}{l}0.249 \\
0.220 \\
0.194 \\
0.171\end{array}$ & $\begin{array}{l}5.61 \times 10^{-2} \\
4.82 \times 10^{-2} \\
3.63 \times 10^{-2} \\
2.33 \times 10^{-2}\end{array}$ & $\begin{array}{l}9.12 \times 10^{-2} \\
8.88 \times 10^{-2} \\
7.59 \times 10^{-2} \\
5.51 \times 10^{-2}\end{array}$ \\
\hline $\begin{array}{l}34 \\
35\end{array}$ & $\begin{array}{l}0.151 \\
0.133\end{array}$ & $\begin{array}{l}1.52 \times 10^{-2} \\
8.30 \times 10^{-3}\end{array}$ & $\begin{array}{l}4,05 \times 10^{-2} \\
2.51 \times 10^{-2}\end{array}$ \\
\hline
\end{tabular}

Table 14. The $1.0-\mathrm{MeV}$ maximum potential $\mathrm{x}$-ray spectrum. $32 \cdot 34$

\begin{tabular}{cccl}
\hline $\begin{array}{c}\text { MORSE 76L } \\
\text { group number }\end{array}$ & $\begin{array}{c}\text { Averge } \\
\text { cnergy, MaV }\end{array}$ & $\begin{array}{c}\text { Number of } \\
\text { photons/goup }\end{array}$ & $\begin{array}{c}\text { Number of } \\
\text { photons/MeV }\end{array}$ \\
\hline 1.18 & - & 0 & 0 \\
19 & 0.986 & $9.03 \times 10^{-3}$ & $2.64 \times 10^{-3}$ \\
20 & 0.870 & $2.07 \times 10^{-2}$ & $6.86 \times 10^{-3}$ \\
21 & 0.768 & $3.16 \times 10^{-2}$ & $1.18 \times 10^{-2}$ \\
22 & 0.678 & $4.43 \times 10^{-2}$ & $1.89 \times 10^{-2}$ \\
23 & 0.598 & $5.26 \times 10^{-2}$ & $2.54 \times 10^{-2}$ \\
24 & 0.528 & $6.21 \times 10^{-2}$ & $3.39 \times 10^{-2}$ \\
25 & 0.465 & $6.93 \times 10^{-2}$ & $4.28 \times 10^{-2}$ \\
26 & 0.411 & $7.65 \times 10^{-2}$ & $5.35 \times 10^{-2}$ \\
27 & 0.362 & $8.18 \times 10^{-2}$ & $6.49 \times 10^{-2}$ \\
28 & 0.320 & $8.56 \times 10^{-2}$ & $7.73 \times 10^{-2}$ \\
29 & 0.282 & $8.84 \times 10^{-2}$ & $9.00 \times 10^{-2}$ \\
30 & 0.249 & $8.73 \times 10^{-2}$ & $1.01 \times 10^{-1}$ \\
31 & 0.220 & $8.09 \times 10^{-2}$ & $1.06 \times 10^{-1}$ \\
32 & 0.194 & $7.20 \times 10^{-2}$ & $1.07 \times 10^{-1}$ \\
33 & 0.171 & $5.99 \times 10^{-2}$ & $1.01 \times 10^{-1}$ \\
34 & 0.151 & $4.66 \times 10^{-2}$ & $8.87 \times 10^{-2}$ \\
35 & 0.133 & $3.13 \times 10^{-2}$ & $6.75 \times 10^{-2}$ \\
\hline
\end{tabular}

Table 16. The 4.0-MeV maximum potential $x$-ray spectrum, ${ }^{34-36}$

\begin{tabular}{|c|c|c|c|}
\hline $\begin{array}{l}\text { MORSE } 76 \mathrm{~L} \\
\text { goup number }\end{array}$ & $\begin{array}{c}\text { Average } \\
\text { encrgy, } M L V\end{array}$ & $\begin{array}{c}\text { Number of } \\
\text { photons/goup }\end{array}$ & $\begin{array}{c}\text { Number of } \\
\text { photons } \mathrm{McV}\end{array}$ \\
\hline 1.7 & - & 0 & 0 \\
\hline $\begin{array}{r}8 \\
9 \\
10 \\
11\end{array}$ & $\begin{array}{l}3.96 \\
3.49 \\
3.04 \\
2.69\end{array}$ & $\begin{array}{l}9.92 \times 10^{-4} \\
1.29 \times 10^{-2} \\
1.82 \times 10^{-2} \\
2.84 \times 10^{-2}\end{array}$ & $\begin{array}{l}2.0 \times 10^{-4} \\
2.0 \times 10^{-3} \\
3.87 \times 10^{-3} \\
6.80 \times 10^{-3}\end{array}$ \\
\hline $\begin{array}{l}12 \\
13 \\
14 \\
15\end{array}$ & $\begin{array}{l}2.37 \\
2.09 \\
1.84 \\
1.63\end{array}$ & $\begin{array}{l}3.48 \times 10^{-2} \\
4.02 \times 10^{-2} \\
4.28 \times 10^{-2} \\
4.58 \times 10^{-2}\end{array}$ & $\begin{array}{l}9.45 \times 10^{-3} \\
1.24 \times 10^{-2} \\
1.50 \times 10^{-2} \\
1.81 \times 10^{-2}\end{array}$ \\
\hline $\begin{array}{l}16 \\
17 \\
18 \\
19\end{array}$ & $\begin{array}{l}1.44 \\
1.27 \\
1.12 \\
0.986\end{array}$ & $\begin{array}{l}4.88 \times 10^{-2} \\
5.51 \times 10^{-2} \\
5.95 \times 10^{-2} \\
6.26 \times 10^{-2}\end{array}$ & $\begin{array}{l}2.18 \times 10^{-2} \\
2.79 \times 10^{-2} \\
3.42 \times 10^{-2} \\
4.07 \times 10^{-2}\end{array}$ \\
\hline $\begin{array}{l}20 \\
21 \\
22 \\
23\end{array}$ & $\begin{array}{l}0.870 \\
0.768 \\
0.678 \\
0.598\end{array}$ & $\begin{array}{l}6.18 \times 10^{-2} \\
5.95 \times 10^{-2} \\
5.83 \times 10^{-2} \\
5.71 \times 10^{-2}\end{array}$ & $\begin{array}{l}4.56 \times 10^{-2} \\
4.98 \times 10^{-2} \\
5.54 \times 10^{-2} \\
6.14 \times 10^{-2}\end{array}$ \\
\hline $\begin{array}{l}24 \\
25 \\
26 \\
27\end{array}$ & $\begin{array}{l}0.528 \\
0.465 \\
0.411 \\
0.362\end{array}$ & $\begin{array}{l}5.30 \times 10^{-2} \\
4.99 \times 10^{-2} \\
4.71 \times 10^{-2} \\
4.19 \times 10^{-2}\end{array}$ & $\begin{array}{l}6.46 \times 10^{-2} \\
6.89 \times 10^{-2} \\
7.38 \times 10^{-2} \\
7.45 \times 10^{-2}\end{array}$ \\
\hline $\begin{array}{l}28 \\
29 \\
30 \\
31\end{array}$ & $\begin{array}{l}0.320 \\
0.282 \\
0.249 \\
0.220\end{array}$ & $\begin{array}{l}3.66 \times 10^{-2} \\
3.00 \times 10^{-2} \\
2.36 \times 10^{-2} \\
1.18 \times 10^{-2}\end{array}$ & $\begin{array}{l}7.38 \times 10^{-2} \\
6.84 \times 10^{-2} \\
6.09 \times 10^{-2} \\
3.47 \times 10^{-2}\end{array}$ \\
\hline $\begin{array}{l}32 \\
33 \\
34 \\
35\end{array}$ & $\begin{array}{l}0.194 \\
0.171 \\
0.151 \\
0.133\end{array}$ & $\begin{array}{l}7.32 \times 10^{-3} \\
5.21 \times 10^{-3} \\
3.84 \times 10^{-3} \\
2.98 \times 10^{-3}\end{array}$ & $\begin{array}{l}2.41 \times 10^{-2} \\
1.96 \times 10^{-2} \\
1.64 \times 10^{-2} \\
1.91 \times 10^{-2}\end{array}$ \\
\hline
\end{tabular}


Table 17. The 6.0-MeV moximum potential $\mathrm{x} \cdot \mathrm{j}$ ay spectrum. $31,37,38$

\begin{tabular}{|c|c|c|c|}
\hline $\begin{array}{l}\text { MoRSE 76C } \\
\text { goup number }\end{array}$ & $\begin{array}{c}\text { Average } \\
\text { enetgy, MeV }\end{array}$ & $\begin{array}{l}\text { Mumber of } \\
\text { phatans/gtoup }\end{array}$ & $\begin{array}{c}\text { Number of } \\
\text { photuns/MeV }\end{array}$ \\
\hline $1-4$ & + & 0 & 0 \\
\hline $\begin{array}{l}5 \\
6 \\
7 \\
8\end{array}$ & $\begin{array}{l}5.69 \\
5.02 \\
4.43 \\
3.96\end{array}$ & $\begin{array}{l}1.13 \times 10^{-3} \\
7.93 \times 10^{-3} \\
1.77 \times 10^{-2} \\
1.77 \times 10^{-2}\end{array}$ & $\begin{array}{l}1.42 \times 10^{-4} \\
1.12 \times 10^{-3} \\
2.84 \times 10^{-3} \\
3.94 \times 10^{-3}\end{array}$ \\
\hline $\begin{array}{l}9 \\
10 \\
11 \\
12\end{array}$ & $\begin{array}{l}3.49 \\
3.04 \\
2.69 \\
2.37\end{array}$ & $\begin{array}{l}3.10 \times 10^{-2} \\
3.02 \times 10^{-2} \\
3.40 \times 10^{-2} \\
3.68 \times 10^{-2}\end{array}$ & $\begin{array}{l}5.29 \times 10^{-3} \\
7.06 \times 10^{-3} \\
9.03 \times 10^{-3} \\
1.10 \times 10^{-2}\end{array}$ \\
\hline $\begin{array}{l}13 \\
14 \\
15 \\
16\end{array}$ & $\begin{array}{l}2.09 \\
1.84 \\
1.63 \\
1.44\end{array}$ & $\begin{array}{l}3.92 \times 10^{-2} \\
4.02 \times 10^{-2} \\
4.26 \times 10^{-2} \\
4.32 \times 10^{-2}\end{array}$ & $\begin{array}{l}1.33 \times 10^{-2} \\
1.55 \times 10^{-2} \\
1.86 \times 10^{-2} \\
2.14 \times 10^{-2}\end{array}$ \\
\hline $\begin{array}{l}17 \\
18 \\
19 \\
20\end{array}$ & $\begin{array}{l}1.27 \\
1.12 \\
0.986 \\
0.870\end{array}$ & $\begin{array}{l}4.64 \times 10^{-2} \\
5.04 \times 10^{-2} \\
5.16 \times 10^{-2} \\
5.35 \times 10^{-2}\end{array}$ & $\begin{array}{l}2.59 \times 10^{-2} \\
3.22 \times 10^{-2} \\
3.71 \times 10^{-2} \\
4.38 \times 10^{-2}\end{array}$ \\
\hline $\begin{array}{l}21 \\
22 \\
23 \\
24\end{array}$ & $\begin{array}{l}0.768 \\
0.678 \\
0.598 \\
0.528\end{array}$ & $\begin{array}{l}6.01 \times 10^{-2} \\
5.87 \times 10^{-2} \\
5.65 \times 10^{-2} \\
5.63 \times 10^{-2}\end{array}$ & $\begin{array}{l}5.56 \times 10^{-2} \\
6.17 \times 10^{-2} \\
6.72 \times 10^{-2} \\
7.59 \times 10^{-2}\end{array}$ \\
\hline $\begin{array}{l}25 \\
26 \\
27 \\
28\end{array}$ & $\begin{array}{l}0.465 \\
0.411 \\
0.362 \\
0.320\end{array}$ & $\begin{array}{l}4.84 \times 10^{-2} \\
4.15 \times 10^{-2} \\
3.31 \times 10^{-2} \\
2.65 \times 10^{-2}\end{array}$ & $\begin{array}{l}7.40 \times 10^{-2} \\
7.19 \times 10^{-2} \\
6.5 \times 10^{-2} \\
5.9 \times 10^{-2}\end{array}$ \\
\hline $\begin{array}{l}29 \\
30 \\
31 \\
32\end{array}$ & $\begin{array}{l}0.282 \\
0.249 \\
0.220 \\
0.194\end{array}$ & $\begin{array}{l}2.06 \times 10^{-2} \\
1.67 \times 10^{-2} \\
1.36 \times 10^{-2} \\
1.02 \times 10^{-2}\end{array}$ & $\begin{array}{l}5.2 \times 10^{-2} \\
\$ .81 \times 10^{-2} \\
4.4 \times 10^{-2} \\
3.73 \times 10^{-2}\end{array}$ \\
\hline $\begin{array}{l}33 \\
34 \\
35\end{array}$ & $\begin{array}{l}0.171 \\
0.151 \\
0.133\end{array}$ & $\begin{array}{l}6.69 \times 10^{-3} \\
4.54 \times 10^{-3} \\
2.83 \times 10^{-3}\end{array}$ & $\begin{array}{l}2.78 \times 10^{-2} \\
2.14 \times 10^{-2} \\
1.51 \times 10^{-2}\end{array}$ \\
\hline
\end{tabular}

Table 18. The 10.0-MeV maximum potential $x$-ray specirum. $31,34,39,40$

\begin{tabular}{|c|c|c|c|}
\hline $\begin{array}{l}\text { HORSE 76L } \\
\text { goup number }\end{array}$ & $\begin{array}{c}\text { Avcrapg } \\
\text { energy, Mey }\end{array}$ & $\begin{array}{c}\text { Number of } \\
\text { phntons/group }\end{array}$ & $\begin{array}{c}\text { Number of } \\
\text { photons/MeV }\end{array}$ \\
\hline $\begin{array}{l}1 \\
2 \\
3 \\
4\end{array}$ & $\begin{array}{l}9.39 \\
8.29 \\
7.31 \\
6.45\end{array}$ & $\begin{array}{l}6.46 \times 10^{-3} \\
1.46 \times 10^{-2} \\
1.91 \times 10^{-2} \\
2.31 \times 10^{-2}\end{array}$ & $\begin{array}{l}5.64 \times 10^{-4} \\
1.44 \times 10^{-3} \\
2.14 \times 10^{-3} \\
2.93 \times 10^{-3}\end{array}$ \\
\hline $\begin{array}{l}5 \\
6 \\
7 \\
8\end{array}$ & $\begin{array}{l}5.69 \\
5.02 \\
4.43 \\
3.96\end{array}$ & $\begin{array}{l}2.60 \times 10^{-2} \\
2.75 \times 10^{-2} \\
2.95 \times 10^{-2} \\
2.45 \times 10^{-2}\end{array}$ & $\begin{array}{l}3.74 \times 10^{-3} \\
4.49 \times 10^{-3} \\
5.47 \times 10^{-3} \\
6.30 \times 10^{-3}\end{array}$ \\
\hline $\begin{array}{r}9 \\
10 \\
11 \\
12\end{array}$ & $\begin{array}{l}3.49 \\
3,04 \\
2.69 \\
2.37\end{array}$ & $\begin{array}{l}3.93 \times 10^{-2} \\
3.42 \times 10^{-2} \\
3.61 \times 10^{-2} \\
3.68 \times 10^{-2}\end{array}$ & $\begin{array}{l}7.76 \times 10^{-3} \\
9.24 \times 10^{-3} \\
1.10 \times 10^{-2} \\
1.27 \times 10^{-2}\end{array}$ \\
\hline $\begin{array}{l}13 \\
14 \\
15 \\
16\end{array}$ & $\begin{array}{l}2.09 \\
1.84 \\
1.63 \\
1.44\end{array}$ & $\begin{array}{l}3.76 \times 10^{-2} \\
3.84 \times 10^{-2} \\
3.91 \times 10^{-2} \\
3.99 \times 10^{-2}\end{array}$ & $\begin{array}{l}1.47 \times 10^{-2} \\
1.71 \times 10^{-2} \\
1.97 \times 10^{-2} \\
2.28 \times 10^{-2}\end{array}$ \\
\hline $\begin{array}{l}17 \\
18 \\
19 \\
210\end{array}$ & $\begin{array}{l}1.27 \\
1.12 \\
0.986 \\
0.870\end{array}$ & $\begin{array}{l}4.34 \times 10^{-2} \\
4.44 \times 10^{-2} \\
4.56 \times 10^{-2} \\
4.40 \times 10^{-2}\end{array}$ & $\begin{array}{l}2.81 \times 10^{-2} \\
3.26 \times 10^{-2} \\
3.78 \times 10^{-2} \\
4.15 \times 10^{-2}\end{array}$ \\
\hline $\begin{array}{l}21 \\
22 \\
23 \\
24\end{array}$ & $\begin{array}{l}0.768 \\
0.678 \\
0.598 \\
0.528\end{array}$ & $\begin{array}{l}4.06 \times 10^{-2} \\
4.06 \times 10^{-2} \\
3.84 \times 10^{-2} \\
3.56 \times 10^{-2}\end{array}$ & $\begin{array}{l}4.33 \times 10^{-2} \\
4.91 \times 10^{-2} \\
5.26 \times 10^{-2} \\
5.54 \times 10^{-2}\end{array}$ \\
\hline $\begin{array}{l}25 \\
26 \\
27 \\
28\end{array}$ & $\begin{array}{l}0.465 \\
0.411 \\
0.362 \\
0.320\end{array}$ & $\begin{array}{l}3.32 \times 10^{-2} \\
3.16 \times 10^{-2} \\
2.93 \times 10^{-2} \\
2.68 \times 10^{-2}\end{array}$ & $\begin{array}{l}5.85 \times 10^{-2} \\
6.31 \times 10^{-2} \\
6.63 \times 10^{-2} \\
6.88 \times 10^{-2}\end{array}$ \\
\hline $\begin{array}{l}29 \\
30 \\
31 \\
32\end{array}$ & $\begin{array}{l}0.282 \\
0.249 \\
0.220 \\
0.194\end{array}$ & $\begin{array}{l}2.33 \times 10^{-2} \\
1.94 \times 10^{-2} \\
1.70 \times 10^{-2} \\
3.00 \times 10^{-2}\end{array}$ & $\begin{array}{l}6.8 \times 10^{-2} \\
6.4 \times 10^{-2} \\
6.3 \times 10^{-2} \\
4.2 \times 10^{-2}\end{array}$ \\
\hline $\begin{array}{l}33 \\
34 \\
35\end{array}$ & $\begin{array}{l}0.171 \\
0.151 \\
0.133\end{array}$ & $\begin{array}{l}2.94 \times 10^{-3} \\
1.30 \times 10^{-3} \\
3.44 \times 10^{-4}\end{array}$ & $\begin{array}{l}1.4 \times 10^{-2} \\
7.1 \times 10^{-3} \\
2.1 \times 10^{-3}\end{array}$ \\
\hline
\end{tabular}




\section{PUBLICATIONS}

J. H. Ellion, Tome of the Stondards and Calibrations Lahoratort. Latwrence Livermore Lihorators, Inermore. Calli., LCRL-52537 (1978).

This tout of the Standards and Calibrations Laberators at LI.L is a guide to the cupatilitices of and services offered by this unique laboratory. We erplain how (1) provide radiation fields and meatsurements for dosineters and describe survey instruments, spectrometters, sourceis, and alvailatle equipment and facilities. The tour also indudes a survey of wome heillh physics and interdepartmentill prourarms supported by the Slandards and Callibration Laboratory and a list of applicable prublications.

E. Farles, J. Becker, K. ('rase, R. Howe, and D. Selway, Measurimeme of Energl Deposited by' Charged Partide Beanss in Commpesite Targets. Lawrence Linermore Laboratory. Lisermore. Callif., UCID. $79-5$ (1979).

No : ibstracl iluailable.

D. A. Fuess, $A$ Complese Sissem for Ponlahle Gamma Spectrowopr, Latwrence Livermort L.aboralory. Livermort. Calif., UCRL-526II (1978).

This puper describes is system huilt around the Computing̨ Garmma Speetrometer (PSA) LEA 740088. The software primarily supporls highresolution tamma-ray spectroscopy using eilher a high-purity intrinsic germanium delettor (HPGe) or a lithium-drifited germanium detector $[G e(L i)]$.

D. A. Fuess, D. R. Slaughter, R, E. Strout, and D. W. Rueppel, Detcrmination of Continuous Ganma-Ray' Spectra Oter the Energ!' Range O.I Io $8 \mathrm{McV}$, Latwrence Livermore Lithoratory, Livermore, Cadlif.. LCRL-52513 (1978).

We have established an experimental facility at LLL to characterize radiation fields produced by a variely of sources and trunsmitted through various shielding materials. We discuss specific techniques for atequiring and reducing continuous gamma-ray energy spectra, including $\mathrm{Nal}(\mathrm{TI})$ detsctors. The usc of several detector sires allowed us to sludy a wide variely of source intensities and 10 calculifte tesponse malricus for a number of collimated detec. tor configurations. We describe a computer program that perlorms dali redustion by an iterative unfulding process. Our reduction technique discloses the continuous gamma-ray energy spectrunl over the range 0,1 to $8 \mathrm{MeV}_{\text {as }}$ opposed to the Iraditionil petak-inlensity analysis.

R. B. Gammage, 'T. Vo-liinh, A. R, Hawthorne, J. H. Thorngate, and W. W. Parkinson, "New Tech. niques for Measuring Polynuclear Aromatics in the Workplute," in Advances in Chemisiry, No. 170 (Americian Chemical Socicty. Washingın, D.C. 1978).

A gap exists herween the crude techniques anylatile for measuring polynuclear aromalic compounds in the workplace and the solphisticated analytical tools used in the laboratory for a much fuller characterization of pollutants from sunthetic fucl uperations such as lar sand and oil shate processing. Real-time or near real-lime instruments suituble for use by industrial hygienists are urgently needed to meusure fugitive emissions. W: describe weveral stew instruments and instrumental lect. niques that could sutisfy some of these needs. They include second-derivative ultraviolel absorption, synchronous luminescence and room-lemperature phosphorescence spectrometries, a portable mass spectrometer, differential sublimation, and therroluminescence. We evaluated the praclicality of these approaches and found that they are suitable for monitoring (1) naphthalene and its alkyl derivitives ut parts-per-billion concentrations cither in the vapor or the solution phase and (2) trace amounts of phenolic compounds in by-product water. They are atso suitable for the rapid analysis of samples filtered or spotted on paper adsorbents.

R. B. Gammage, J. H. Thorngate, W. W. Parkinson, A. R. Hawthorne, and T. Vo-Dinh, "On the Desirability of the Health Physics Society Assuming Responsibilities in the Nonnuclear and Nonradittion Fields," Health Phis. 35. $7 \mid$ (1978).

No ubstracl ivailable.

C. A. Harder and B. J. Held, "Operation of SelfContained Breathing Apparatus Exposed to Low Air Temperaturc," The International Fire Chief 45(l), 6-10 (1979). 
To deturmine the effect of cold and thermal shook on self-contained hreuthing asparalus, wo have conducted subjective and instrumented low air temperature studies and instrumented thermal shock tests from low to high air lemperatures. The results will hisp Lawrence livurmore Labordtory Tirulighters and emergency leams sclect apparaitus for use II fires and emergencies at off-sile energy projicts located in cold climales. In the subjective lests, users evalualed the performannee of apparalus thit had heen cold soaked for $24 \mathrm{~h}$ at $-25^{\circ} \mathrm{F}$. For the instrumented tests. we monilssed air pressures in pressurt-demand filcepieces exposed to temperatures of -25 and $-4 I^{\mathrm{p} F}$. We also monitored air presules during a $\mathrm{l}$-h period in which the air tem. perature rithe frem -25 to $2017^{\circ} \mathrm{F}$. Some models nowed subatmospheric inhalition pressures at subcro lemperatures. ohers developed problemss and the flow-air pressure alarms un all models fialed to sound at $-40^{\circ} \mathrm{F}$. Thermal shocking of the coldwaked apparates did not uppear to affect the operaling charicteristics of any noded al cither fow or high air lemperalures.

C. A. Harder and B. J, Held, "Future Research Sieveds for Firu Fighters' Broul hing Apparatus," The International Fire Chice 45(3), 26-30 (1979).

In this article we discuss current and planned research to determine how factors such as radiant heal, neisture, ullea-high air emperatures, liredecomposition products and chemicals, exlinguishing ingen Is, and mechanical stress may affect the opscation and use of firc fighters" breathing apparalus. We also diseuss the necd for improved communicalions between apparutus wearers,

C. A. Harder and B. J. Held, "New Stundurds, Regulations, and Propusals for Sell-Contained Brealhing Apparalus," The Imernational Fire Chief 45(4), $23-27$ (1979).

In this article, we look at the changing state and federil standirds for self-contained breathing apparalus and their elfect on the fise service. We also discuss the curpent activitics of various government and standard-setting organizations and the changes that may result from these sctivities,

A. R. Hauthorne and J. H. Thorngate, "Improving a nalusis from Second-Derivative Ultraviole:$\therefore$ sir:ption Spectrometry," Applied Optics 17, 724

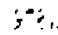

$\because$ :arest anailable.
A. R. Hawthorne and J. H. Thorngate, "Applicile lisns of Second-Derivative Uhreviolu-Absorption Spectrometry to Polynuclear Aromatic Analysis," Applied Spectrometry (1978).

The increwsed awareness of the deleterious to fects of polynuclear aromatic compounds emphasizes the need for instrumernts that are capable of monitoring thesc compounds and stritable for use in health prolection programs. Sccond-derivatisc ultriviolet-absorption spectrometry ..., h letsl-squares spectral andigsis in a promising melhod for inalyzing vapos phast polynuclear aromatics and solutions containimg these compounds. Detection limits of a lew parts per billion are altainable for many polynuelear aromallic compounds. The examples we pive show the analytical capabilities of this method.

A. K. Uawthorne, J. H. Thorngate, R. B. Cammage, and T. Vo-llinh, "Development of a Prototipe in. strument far Field Monitoring of Polynuclear Aromalic Vipors" (in Proc. Third Insern. S!mp. Polymuclear Aromatic Hydrocarhous. Columbus. Ohiw. 25-27 Oitoher 1978).

Cisl conversion facilitits are a new and ponen. tially large source of man's expessure to polynuclear ar omititics. But with the ever dwindling sources of pelfoleum and the increased dependence on forcign vil, the U.S. Depitrment of Energy is comnitted to developing coal resources, espectially for the production of synthetic fuels. An important part of this commitment is to ensure that there are minimal adverse effects on human health and the enviranment as a result of new energy lechnologits. This includes efforls to ensure that adequate industrial bygiene meisures are provided to protect workers from exposure to polynuclear aromulics. This paper describes the development of a porlable field monitor that can provide reul-time meusurement of volatile polynuclear aromatics in various work areas.

\section{G. F. Hunt, A Microprocessor Controlled, Persomt} Thermoltuninescence Dosimetry Reader, Lawrence Livcrmore Laboratory, Livermore, Callif. UCRL. 81153 (prepared for submission to the IEEE Nucleur Science Symposium, Washinglon, D.C., Octobur 18-20, 1978).

Using a DEC LSI-11 microprocessor, we have developed a thermoluminescence dosimeiry reader for personnel dosimetry. This microprocessor 
provides sistem control, accumulales datu for temporary storage on a cassette, and Jaler outpuls the dalid to al large computer. The microprocessor also provides a human/system interface through a com. puter terninal. A programmable high-voltage supry and a light-emilting diode are used in the reader system to automatically' control photomultiplier tuhe guill.

J. S. Johnson, Lawrence Livermore Lahoratory's Bergllinm Connrol Prongram for High-Explustie Test Firing Bunten and Tables, Lawrence Livermore Labacitary, Livermare, Calif, UCID-18006 (1978).

This detailed report on Latwrence Livermore Laboratory's comerol progran to minimize berslium lesels in Lithoratory workplaces includes an outlins of hesylliun sur[aces soi], and aif icrels and an I I-ycar stanmary of sampling results from ino high-use. high-explosive lest firing bunkers. These sampling ditia and other studies demonstralc llat the heryllium control program is functioning elfecinely.

J. S. Johnson, "The Acule Foxicology of TATB," Proc. Slmp. Chemistry of 2,2',4,4',6,6'Hexamitrostithene (HNS) and 1,3,5-7riamino, 2,4,6. Triaminubenzen' (TATB), Wallham Abbey, Essex, England, 28 March 1979 (Propellants, Explosives and Rockut Matur Estahlishment, Essex, England, 1979 .

The acute foxicology of TATB and swo of its ynthutic precursors, 1,3.5. trichlorobenzene and 1.3 .5 trichloro-2,4,6-trinitrobernacne, is presented. We describe each acute asxicology test and give typical cesamplen of the industrial hygicne controls used for handling these muterials.

\section{J. S. Johnson, Safe Handling of Chemical Car-} cinogens in the Researdh Laboratory, Lawence Livermore Luburatory, Livermore, Calif, UCRL$\$ 2387$ iprepared for presentation at the 177 th meeting of the American Chemical Sociely, held jointly with the Japanese Chemical Sociely, Hımolulu. Hawaii. April 2-6. 1979).

Toxic and cortosive chemicals have been a part of America's development for several decades. Only in the last 30 years, however, has any national regulatory attention been given to the safe handling of such chemicals in the workplace. The use of toxic and comosive materials in the workplace was formally regulated by the Occupational Safety and
Health Act of 1970; in 1973, the Occupational Health and Sifely Administration issued temporary emergency standards for 14 chemical carcinogens. Now this administration is attempting to promulgate u generic carcinogen control standard. Liarence Livermors Laboratory has established a chenical carcinogen control program on the basis of applicuble standards promulgited ty the Occupational Safely and Health Administration and has supplemented the program with internal controls for the sale handling of chemical carcinogents in the research laboratory. That control program is oullinid here.

G. O. Nelson, Calibration Techniques, Lawrence Livermure Lahoritory, Livermors. Calid, UCRL82468 (1979).

This report compares the simple static and the more complex dinamic melhods of gus standard generation. A completely automiled flowtemperature-hanjdity-concentration controller is also described.

G. O. Nelson and R. D. Taylor, FlonTemperature-Humidity. Control System Operating Manwal, Lawtence Livermore Luboralory, Livermore, Culif., UCID-17961 (1978).

This manual contains operating. mantenance. and trouhleshooting procedures for the llowtempifature-humidity control system used at the Lawrence Livermore Laboratory to prepare test atmospheres for industrial hygiene and air pollution studies. The systen consists of two basic components: a commercially available temperature; humidity indicator unit and it specially built flow-temperacure-humidity control moduit. Procedures are given for using the control system with a vapor generation system or with a trace-gas flowmeter to add vapor or a trace gas to the disstrean after it leaves the control module.

D. R. Slaughter, D. W. Rueppel, and D. A. Fuess, Neutron Spertmon Measurements for Radiation Protction Purposes. Lawrence Livermore Liboralory, Livermore, Calif. UCRL-52415 (1978).

We have mealsured the encrgy spectea of lowintensity neutron sources used for calibraling personnel neutcon dost-ralte melers and dosineters and for churacterizing the neutron fitelds to which personnel are exposed. This reporl dextribes severul detcetor-analyzer systems that meusure in the 
energy range $50 \mathrm{keV}$ to $20 \mathrm{MeV}$ at intensities from $10^{-1}$ to $10^{5} \mathrm{r} / \mathrm{cm}^{2}-\mathrm{s}$. The systems include NE213 and Sillbenc organie scintillators as weli is $\mathrm{H}_{2}{ }^{\mathrm{J}} \mathrm{He}$, and $\mathrm{CH}_{4}$ proportional counters. Also described are pulse-height analysis and puisce-shape discriminaion susecrs. An unfolding code, NUTSPEC. reduces the pulse-height diatil to an absolute dif. ferentiall neutron flux w(E) for the ahove detectors. The code uses a derivalive unfolding method for the scintiflation delectors, and for the proportional cosunters it culculates it response matrix and uses in ilerative unfolding method to determine unfolded flux distribution, combined with published conversion lictors, produces dirferential neutron desce-expivalent and kermu rates. Spectral seyments ohtained with different delectors from several metsurements merge into a single differential flux spectrum over the range $50 \mathrm{keV}$ to $20 \mathrm{McV}$. together with the corresponding differential kerma and neulron dost-equivalent distribulion. Also reporled arce snectrum meusurenients near ${ }^{252} \mathrm{C} \int$ and

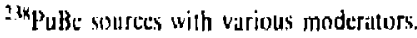

J. H. Thorngate, Practical Considerations for the Applicution of Neutron Spectrascopy to Radiation Protertion. Lawrence Livermore Laboratory. Livermore, Calif., UCRL-81738 (prepared for submission to Health Phyrics, 1978).

Dosimetric ennsideritions control the use of neutron spectroscopy in radialion protection. Detuiled information ahout the energy distrihution of the neutron field is required only in regions where the fleence-to-dose-equjvalent conversion factor is a sapidly changing function of energy. Thus, although Duence measurements must be made, spectrid afe not required for energies below $10 \mathrm{keV}$ and probably are ilso unnecessiry in the energy region from $20 \mathrm{McV}$ to several hundred McV. A lower limit of $50 \mathrm{ktV}$ and an upper limit of $6 \mathrm{MeV}$ are reisonable for many practical eases. Between 10 $\mathrm{keV}$ and $20 \mathrm{MeV}$, an energy resolution of $20 \%$ is sufficiem to stay vithin $10 \%$ of the conversion fac1or. Proportional counters filled with gass and liquid orgenic stintillators provide adequate sensitivity and resolution. Normwity, more than one delector will be required foi adequite medsurements. The system should also include an on-line computur to simplify the operation of :hs instrument and to reduce line data rapidy.

T. Vo-Dinh, R. B. Gammage, A. R. Hawthome, ind J. H. Thomgate, "5ynchronuus Spectroscopy for the Analysis of Polynuctear Aromatic Compounds," Envirm. Sci. and Tech. 12, 1297 (1978).

No abstract available.

C. M. Wong, J. L. Cate, and W. L. Pickles, Preparation of Uranium Standard Sulutions for $x$ Reḷ Fhurescence Analysis, Lawrence Livermore Laboratury, Livermore, Calif.. UCRL-80778 (prepared for presentation at the Ameritan Nuclear Suciely Topicil Conference, Williumsburg. Virginia, May 15-17, 1978).

No absilract alvailable. 


\section{REFERENCES}

1. N. J. Alvaress, A. E. Lipska, and D. G. Beason, "HEPA Filter Fïe Protection," in Hazards Conmol Progrets Repon No. 56. Jantuarl through Seperember 1978, Lawrence Livermore Lahoratory. Livermore, Cullif., UCRL-50007.78-1 (1979).

2. J. L. Calc. Jr., "On-Line X-Ray Fluorescence Analysis of Transition Metals in Waste Water: Phase I," in Hazard Comlerol Progress Repon No 55, Julr through December 1977, Lawrence Livermore Lathoratory. Livermort, Cylif,. UCRL-50007.77.2 (1978).

3. C. A. Harder, B. J, Held, ind G. J. Cardenas, "Operation of Self-Contained Breathing Apparatus Expused w High Air Tenpursutures," The Imematimal Fire Chief 4(12), 8.14 (1978).

4. C. A. Harder and B. J. Held. "Operiation of Self-Contained Breathing Apparalus Exposed to Low Air Temperatues." The mermational Fire Chief 45(1), 6-10 (1979).

5. C. A. Harder and B. J. Held. "Future Rescarch Nueds for Fire Fighters" Breathing Apparatess." The Internutiomul Fire Chirf 45(3). 26-30 (1979),

6. W. L. lickles and J. H. Lilliotl. "Neutron Spectrometer," in Hosards Control Progress Repturt No. 44

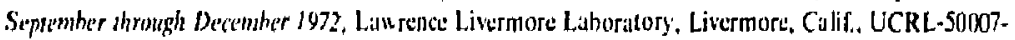
72.3 (197.3).

7. J. H. Ellioti. W. L. Pickles, and D. R. Slizughter, "Neutron Spectromelry," in Hazards Comlrol Prugress Reparn. Lo 4h Januery through April 1973. Lawrence Livermure Lathoritory, Livermore, Calif., UCRLS(10007-73-2 (1973).

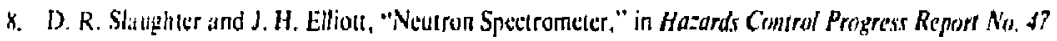
Segtember through Decemher 1973. Liwsence Livermore Lahoratory, Livermore, C.lif., UCRL-500077... $3(1974)$.

9. J. H. Elliont and D. R. Slaughter. "Neutron Spectrometer Development," in Hozards Comrol Progress Repurn Mis 48 Jatuary through hume 1974, Liarence Livernore Laboratory, Livermore, Calif., UCRI. $50007-74-1$ (1974).

11). D. R. Slaughter and J. H. Ellioll, "Neutron Spectrometcr Development." in Hazards Comtrol Progrets Report No. 49 July alrough Decenter 1974, Lawrence Livermore Laboratory. Livermore. Calif.. UCRL. 501007-74-2 (1975).

1I. D. R. Slaughter and D. W. Rueppul, "Neutron Spectromeler System." in Hazard; Control Progress Repurn No. Sn January through June 1975. Lawrence Livermore Lahoratsry, Liwirmore, Calif., UCR1. 50007. $75-1$ (1975).

12. D. R. Slaughter and D. W. Rueppel, "Development of a High-Resolution Sicutron Spectrometer for Field Use," in Hazards Control Progress Reporn No. 50 January through June 1975, Lavirence Livermore Laboritory, Livermort, Calif., UCRL-50007-75-1 (1975).

13. D. R. Slaughter and D. W. Rueppel, "Calibralion of Proportional Counters for Neutron Spectrometer," in Hazards Comtrol Prograss Report No. So January through June 3975, Lawrente Livermore Laborators, Livermore, Cillif., UCRL-50007-75.1 (1975).

14. D. R Slaughter, R. C. Kaifer, D. Fuess, and D. W, Rueppel. "Nitutron Spectroscopy in the Energy Range 0.5-20 MoV Using a NE213 Scintillator," in Hasards Comrol Progress Reporı No. 53 Jul! through December 1976, Lawrence Livermore Laborilory, Livermore, Calif., UCRL-50007-76-2 (1977).

15. D. R. Slaughter. D. W. Rueppel, and D. A. Fuess, Neutron Spectrum Measurements for Radiation Protection. Lawrence Livernore Laboratory, Livermore, Calif., UCRL-52415 (1978).

16. P. W. Bunjamin, "The Use of Recoil Proton Mcthods for Measuring Neutron Spectea in a Fast ReacLor," in Proc. Stmp. Neufrom Detection, Dnsimemy and Standardization, Hartell, 16-14 Decennber 1962 !hiA, Vitpni, 1963), vol. II. p. 307.

17, J. W. Weule, P. W. Benjamin. C. D. Kemshall. W. J. Paterson, and J. Readfern, "Neutron Measurements in the Zero Power lass Restlor VERA." in Proc. Intern. Conf. Radiation Measurements in Nuclear Pstrer, Berkeley, England, 1966 (Insitute of Phỵics and The Physical Society, London, 1966) pp. 231-244. 
18. H. Werle and H. Bluhm, "Fissivil-Neutron Spectra Metsurenents of ${ }^{235} \mathrm{~L},{ }^{239} \mathrm{Pu}$ and ${ }^{252} \mathrm{Cf}$." $/$. Nucl. Encrgy 26, 165-176 (1972).

19. 11. Ing and S. Makrid, "Compendium of Neutron Spectra in Criticality Accident Dosimetry," in MEA Technical Reports Serics No. IKO (IAEA, Vienna, 1978).

20. J. A. Auxier, W. S. Snyder, and T. D. Jones, "Necutron Interactions and Penetralion in Tissut;" in Radiatien Dessimerry. F. H. Altix and W. C. Roesch, Eds. (Academic Press, New York, 1968).

21. T. K. Alexander and F, S. Foulding, "An Amplitude-Insensitive System That Distinguishes Bulses of Different Shapes," Nucl. Instrum. \& Methods 13, 244-246 (1961).

22. 1. Gatt and F. de Martini, "A Ncw Linear Method of Discrimination Belween Elementary Parlistes in Scintillbulion Counters," in Proc. Cortf. Nuclear Elecaronics, Belgrade, 15-20 May IS6/ (IAE:A, Viennil. 1962), ก. 26.5 .

23. C. L. Murris, J. E. Bolger, G. W. Hoffman, C. F. Moore, L. E. Smith, and H. A. Thitssern, "A Digital Techniqute for Nicutron+Gamma Pulse Shape Discrimination, "Nucl. Insirum. and Metheds 137, 397.398 (1976).

24. B. Sabbath and A. Suhami, "An Accurate Puls-Shape Discriminator for a Widt Randte of Energies," Nud. Inirnim. \& Nethods 58, 102-110 (1968).

25. F. T. Kuchnir and F. J. Lynch, "Tine Dependenee of Scintillaars and the Eifect on Pulse-Shitpe Discrimination." IEES Trans. Nuct. Sci. 15(3), 107-113 (1968).

26. A, Bertin. A. Vitile, ind A. Plecei, "The Response of Large Volune NE213 Liquid Scintillalors to bilecIrons and Protons," Nutl. Insmam. and Methosk 91, 6-99-652 (197)).

27. V. V. Verbinkki, W. R. Burrus, I. A, Love, W. Zobel, and N. W. Hill, "Culibration of an Organic Stintillitor far Neutron Spectrometry," Nud. Insinmm. \& Methods 65, 8-25 (1968).

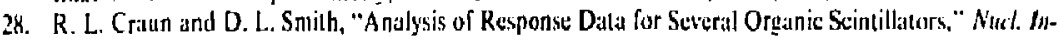
strum. and Merhouds 811. 239-244 (1970).

29. H. H. Andersen and J. F. Ziegler, Hydrogen Stupping Powers and Ranges in All Elements. The Slopping and Runges of lons in Malter, vol. 3, J. F. Zisgler, Ed. (Pergamon Press, New York, 1977).

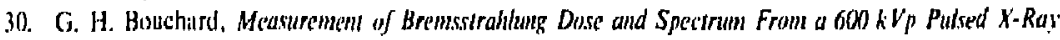
Gemuratur Using Plntographic Film. Sandia Corn., Albuquturque, New Mexico, TID-1604l (196?).

31. J. L. Dutch, Jr., Edgerton, Gurmeshususen \& Grier, Ine, private conırnunication (Detember 1977).

32. E. Tochilin and N. Goldstein, Dose Rate and Spectral Measurememts From Pulsed X-Raj' Generaions, U.S. Nival Rudiological Defense Laboratory, San Francisco, Cilif., USNRDL-TR-939 (1965).

33. E. A. Edelsack. W. E. Kreger. W. Mallet, and N. E. Scofield. "Experimental Investigation of Thick Tasget Bremsstrahlung Radiation Produced by Electrons of 1.00,1.50, and 2.00 meV, "Healh Phis. 4, i-15 (1960).

34. W. C. Dickinson and E, M. L.tnl, Calculation of Forward Bremsstrahlung Spectra from Thick Targess. Lisyrence Livermort Luboratory, Livermore, Calif., UCRL-5-442 (1968).

35. 1. C. Gulden. Jr., Analytical Expressions for Bremsstrahlung Specira Emitted by Highly filtered, Thick High $Z$ Targeted X-Ray Detices from $21020 \mathrm{MeV}$, Sundiu Corp., Albuquerque, New Mexico, SC.TM67-2900 (1967).

36. H. H. Hansen, W. G. Connor, K. Koppks, and M. M. L. Boone, "A New Field Flattening Filter for the Clinac-4," Radiology' 103(2), 443-446 (1972),

37. A. A. O'Ditl, Jr. C.W. Sandifer, R. B, Knowlen, and W. D. Geurge, "Measurement of Absolute ThickTarget Bremsstrahlung Spectra," Nucl. Instrum, and Methods o1, 340-346 (1968).

38. L. B. Levy, Experimental and Calculated 2, 6, 8. 19, and 25 MeV Bremisstrahtung Spectra from Medical Electron Accelerators, Ph.D. thesis, University of Texas, Sun Antonio, Texils (1974).

39. A. M. Chodorow, HERMES II Experimenters' Manual, Sandia Laboratories, Albuquerque, New Mexico, SC-M-70-242 (1970),

40. H. Ferdinande, G. Knuyt, R. Jon de Vjver. and R. Jacobs, "Numerical Calculation of Absulute Forward Thick-Tatget Bremsstrahlung Spectra; Nud, Imstrum. \& Methods 91, 135-140 (1971). 